NBER WORKING PAPER SERIES

WHEN ECONOMIC REFORM GOES WRONG: CASHEWS IN MOZAMBIQUE

\author{
Margaret McMillan \\ Dani Rodrik \\ Karen Horn Welch
}

Working Paper 9117

http://www.nber.org/papers/w9117

\author{
NATIONAL BUREAU OF ECONOMIC RESEARCH \\ 1050 Massachusetts Avenue \\ Cambridge, MA 02138
}

August 2002

\begin{abstract}
We would like to thank Dr. Raimundo Matule (Deputy Director of INCAJU) for meeting with us in New York and commenting on an earlier draft. We also thank Jehan Arulpragasam, Sidney Bliss, Ewen Cobban, Jaikishan Desai, John Fynn, Joe Hanlon, Nicholas Kottak, Ana Machalela, Graham Mann, Paulo Mole, Peter Moll, Timothy Mooney, Patrick Nicholson, Dan Owen, Jean Penvenne, Phyllis Pomerantz, Pankaj Sampat, Arnold Sowa, Finn Tarp, German Vegarra, Michael Weber and Johannes Zutt for taking the time to communicate with us and for providing us with data and documentation. We thank William Masters for extensive comments on an earlier draft and Lynne Pepall for several helpful conversations. Needless to say, we alone are responsible for remaining errors of fact, interpretation, and judgment. The authors are grateful to the Ford and Rockefeller Foundations for financial support. The views expressed herein are those of the authors and not necessarily those of the National Bureau of Economic Research.
\end{abstract}

(C) 2002 by Margaret McMillan, Dani Rodrik and Karen Horn Welch. All rights reserved. Short sections of text, not to exceed two paragraphs, may be quoted without explicit permission provided that full credit, including (C) notice, is given to the source. 
When Economic Reform Goes Wrong: Cashews in Mozambique

Margaret McMillan, Dani Rodrik and Karen Horn Welch

NBER Working Paper No. 9117

August 2002

JEL No. O10, O50, F10

\begin{abstract}
Mozambique liberalized its cashew sector in the early 1990s in response to pressure from the World Bank. Opponents of the reform have argued that the policy did little to benefit poor cashew farmers while bankrupting factories in urban areas. Using a welfare-theoretic framework, we analyze the available evidence and provide an accounting of the distributional and efficiency consequences of the reform. We estimate that the direct benefits from reducing restrictions on raw cashew exports were of the order $\$ 6.6$ million annually, or about $0.14 \%$ of Mozambique GDP. However, these benefits were largely offset by the costs of unemployment in the urban areas. The net gain to farmers was probably no greater than $\$ 5.3$ million, or $\$ 5.30$ per year for the average cashew-growing household. Inadequate attention to economic structure and to political economy seems to account for these disappointing outcomes.
\end{abstract}

Margaret McMillan

Department of Economics

304 Braker Hall

Tufts University

Medford, MA 02155

margaret.mcmillan@tufts.edu
Dani Rodrik

JFK School of Government

Harvard University

79 JFK Street

Cambridge, MA 02138

and NBER

dani_rodrik@harvard.edu
Karen Horn Welch

87 Hulme Court, Apt. 5c

Stanford, CA 94305

horn_karen@yahoo.com 


\section{When ECONOMIC Reform GoEs Wrong: CASHEWS In MoZAMBiQue}

\section{Introduction}

In a case that has become a cause celebre for the anti-globalization movement, the World Bank prevailed on Mozambique's government in the early 1990s to liberalize the cashew sector and to remove restrictions on exports of raw cashews. The Bank hoped that resources would be allocated more efficiently and the incomes of cashew farmers would be boosted. The policy was met with fierce opposition from the domestic cashew-processing industry, which ironically had just been privatized. After a decade of political strife, international controversy, and ongoing if hesitant reform, the consequences remain hotly contested. Each side in the debate has its favorite statistics: the World Bank points to the rise in farmgate prices, while its opponents point to the processing plants in urban areas which have been shut down and the thousands of workers that remain unemployed.

Historically, the cashew sector has constituted a significant part of Mozambique's economy, providing income to several million individuals across the country. In the 1960s, Mozambique produced as much as half of the world's total. The sector went into a long decline thereafter, as a combination of adverse policies and civil war (1982-1992) brought new tree plantings to a halt. Following independence in 1975, the government had banned the export of raw cashew nuts to stimulate domestic processing. Mozambique became the first African country to process cashews on a large scale. By 1980, the country had 14 processing factories. Following World Bank advice, the government began to loosen restrictions on raw cashew production in the late 1980s. The ban on exporting raw cashews was lifted in 1991/92 and replaced with an export quota and export tax. The quota was subsequently removed, and the export tax on raw nuts came down from $60 \%$ in $1991 / 92$ to $14 \%$ in $1998 / 99$.

From the vantage point of textbook economics, the analysis of the export restriction and its removal is a straightforward exercise. A ban (or tax) on exports depresses the domestic price of raw cashews, effectively subsidizing the domestic processors for whom raw cashews is the chief input. The policy results in an inefficient allocation of resources: raw cashew production is discouraged, and labor and capital are pulled into cashew processing where, absent externalities, their social value marginal product is lower than in other activities. The relaxation of the restrictions is therefore expected to create a double benefit. First, an efficiency gain, arising from the reversal of the adverse resource pulls mentioned above. And second, a distributional gain, resulting from the rise in farmgate prices for the poorest households in Mozambique. This is the sort of analysis that underlies, for example, Paul Krugman's (2000) New York Times column on the subject, which took the anti-World Bank crowd to task for overlooking the propoor bias of the export liberalization.

As we shall show in this paper, many of the textbook implications of export liberalization were indeed realized. Farmgate prices rose, raw cashew exports increased, and resources were pulled out of cashew processing. However, even under the most favorable assumptions, the magnitude of the benefits generated by these effects were quite small — both in economic terms and in relation to the amount of time and energy that Mozambique's government spent on this question over the years. We estimate that the efficiency gains generated by the removal of the export restrictions could not have amounted to more than $\$ 6.6$ million annually, or about $0.14 \%$ 
of Mozambique GDP. The additional income accruing to the farmers was probably no greater than $\$ 5.3$ million, or $\$ 5.30$ per year for the average cashew-growing household. These are puny amounts for a policy that was a key plank in the World Bank's reform agenda, and that became a serious bone of contention between the Bank and Mozambique, requiring the personal attention of both of their presidents.

Moreover, small as they are, these numbers overstate the benefits involved. The standard gains from the liberalization have to be set against the efficiency losses that have resulted from the idling of processing plants. In theory, the workers employed in these plants should have found alternative sources of employment after a reasonable time, perhaps suffering some wage losses in the process. In reality, a large number seems to have remained unemployed, perhaps because of the expectation that the liberalization would be eventually reversed. One account claims that $90 \%$ of the sector's 11,000 workers were unemployed in 2001 . Even if we take a fraction of this number, the loss in real output (equivalently, loss of real income of workers) that is involved is of the order of $\$ 6.1$ million, or $0.12 \%$ of GDP. Note that this amount is roughly equivalent to the direct efficiency gain generated by the liberalization (as noted above). In all likelihood, therefore, the aggregate static gains produced by the liberalization were a wash.

These disappointing outcomes are due in part to wrinkles that the textbook analysis sets aside. First, there are complications that arise from imperfect market structures. We highlight two of those in the analysis below. Domestically, there are several layers of intermediaries that separate cashew farmers from the export trade, creating a situation analogous to doublemarginalization in the analysis of vertical relationships in industrial organization. The chief implication of this is that we cannot expect increases in export prices to be passed one-for-one on to the farmers. The pass-through coefficient is much smaller than unity-more of the order of 40-50\%--reducing the gains that accrue to the poorest households. In other words, traders capture much of the benefits from the liberalization. Externally, we have the complication that the world market for raw cashew is significantly less competitive than that for processed cashew. In effect, India is a monopsony buyer of raw cashew from Mozambique. Mozambique's transformation from an exporter of processed cashews to an exporter of raw cashews can be expected therefore to produce a terms-of-trade loss for the country, which diminishes both the efficiency and distributional gains from liberalization.

The real hope for the liberalization strategy might, and should, have been placed on the dynamic effects. We emphasize two dynamic consequences in particular. First, the liberalization could have reinvigorated the rural sector over the medium- and long-run by reversing the dramatic collapse in cashew tree planting. Second, in the urban sector it could have heralded a restructuring of production by promoting a more rational investment pattern. The key in both instances was a credible commitment to a new pricing regime-possibly complemented with compensatory programs - that would have made it worthwhile for farmers, entrepreneurs, and workers to undertake investments that would be at least in part irreversible. The main failing of the cashew liberalization policy, in our view, was that it did not send sufficiently credible signals about the pricing regime. The result was that farmers refused to plant trees, cashew processors refused to take their resources elsewhere, and urban workers refused to look for other jobs. Had these adjustments taken place instead, the static losses would have been minimized, while the efficiency gains would have grown over time. 
The Mozambique cashew story illustrates several themes that have become increasingly central in the analysis of reform. One theme has to do with the importance of credibility and the need for expectations management. The supply responses that will make reform successful are likely to be forthcoming only when there is sufficient credibility attached to the change in the policy regime. That in turn requires creative thinking on credibility enhancing mechanisms as an integral part of reform. The second theme is that reform is a "political" problem as well as a "technical" one. Had the political opposition of the urban groups been anticipated, or factored in, compensatory mechanisms and side bargains could have been worked out beforehand. Third, policy reform via conditionality is rarely conducive to desirable outcomes. The credibility problems noted above were created in part because the liberalization of the cashew sector was viewed as a "World Bank policy" - something that the government was doing not because it was a priority but because it was required to qualify for World Bank (and IMF) lending. Not having full ownership of the reform, the government was poor at selling it.

There are also implications for the acrimonious turn that the debate on globalization has taken of late. We have little doubt that most of the activists that have attacked the World Bank over its handling of the Mozambique cashew issue have their hearts in the right place. But few have carefully scrutinized the question that one would think they would have been most interested in: are the poorest farmers getting a better price for their product, and are they better off as a result? But the economists are not without blame either. They have relied on a priori generalizations and textbook expositions instead of figuring out what has really transpired on the ground.

Beyond Mozambique are there also implications for the rest of Sub-Saharan Africa (SSA), where $75 \%$ of the labor force still depends entirely on agriculture for its livelihood? Recent evidence suggests that — as in Mozambique - the supply response to price liberalization throughout most of SSA has been disappointing (UNCTAD, 1998). Over-reliance on price reforms is likely to be one reason for this. Most policymakers would agree that price and nonprice incentives are both important determinants of supply. In practice however, it is price reforms that have been carried out most often. It is far easier to stop regulating producer prices than it is to remove structural constraints like poor roads, lack of access to credit, or monopsony power on the part of domestic traders. The problem with price reforms is that they can be also reversed with the stroke of a pen. As our analysis of Mozambique suggests, a significant supply response is unlikely unless there is a sharp break in farmers' expectations about the future. Since non-price reforms are harder to reverse, they may be more effective in increasing the expected profitability of investment from the farmers' point of view, thus eliciting the elusive supply response.

The plan of the paper is as follows. Section 2 provides a capsule history of the cashew industry and of recent developments. Section 3 presents an analytical framework and a decomposition of the welfare effects of cashew liberalization into various channels. In section 4, we provide quantitative estimates of the efficiency and distributional implications of the liberalization. Sections 5 and 6 deal with domestic and international market structure complications, respectively. Section 7 focuses on the domestic processing industry and presents estimates of the unemployment loss. Section 8 speculates on the reasons behind the 
disappointing supply response. Section 9 concludes. A synopsis of the debate surrounding the case is presented in Appendix A.

\section{History of cashew industry and background ${ }^{1}$}

Cashew production has been extremely important to Mozambique throughout much of the 20th century. ${ }^{2}$ The Portuguese promoted cashew cultivation during the colonial period and by the 1960s Mozambique had established itself as the world leader in cashew production. Shortly after Mozambique gained independence from Portugal, cashew production went into a long period of decline (as illustrated in Figure 1). Cashew production is still depressed in spite of efforts to revive the sector. Nevertheless, cashew remains one of Mozambique's leading exports and a source of income to more than one million peasant farm families or approximately 5 million people.

Mozambique's early success in the production of raw nuts was accompanied by a boom in its cashew processing industry (see Figure 1). Mozambique became the first African country to process cashews on an industrial scale as small, manual processing systems were replaced by large, mechanized factories (Deloitte and Touche, 1997). The first industrial plant was established in 1950 and two decades later there were 14 processing factories with a total processing capacity of approximately 150,000 tonnes of raw nuts. Processing of cashew peaked in 1973 when 149,800 tonnes of cashew were processed for export. Since this time, the industry has declined dramatically and in 1999/00 Mozambique processed a total of only 8,000 tonnes of raw cashew (INCAJU, 2001).

In an attempt to stem the decline in processed cashew exports, the Mozambican government banned the export of raw cashew in 1978. But in 1982, a decade long civil war broke out and - as illustrated in Figure 1 - this long period of political turmoil took a toll on both cashew production and processing. Cashew production peaked in 1973 at 240,000 tonnes and has never since achieved that level. At the same time, world cashew production increased steadily and by the late seventies Mozambique had lost its dominant position in cashew production to India and Brazil. By 1989/90, Mozambique produced only 22,106 tonnes (INCAJU 2001) and its share of world raw cashew nut production had dropped to 5\% (Desai, 2001a). Since that time, the range of cashew production has become much smaller, fluctuating only between 22,106 and 66,510 tonnes.

Even during its most successful years, the cashew industry in Mozambique has been highly regulated. Prior to independence, the Portuguese government established producer prices and marketing margins throughout the cashew marketing chain (Tarp, 1990) ${ }^{3}$. During the post-

\footnotetext{
${ }^{1}$ Appendix B provides a detailed timeline of the events surrounding the cashew industry since 1950.

${ }^{2}$ The cashew tree is not indigenous to Mozambique, but was initially imported from Brazil by Portuguese colonists in the $16^{\text {th }}$ century (Nomisma, 1994). The tree is well-suited to the Mozambican climate, particularly in the northern region of the country. Beginning in the 1930s, cashew cultivation in Mozambique expanded dramatically, primarily on small and medium scale African farms (Newitt, 1995).

${ }^{3}$ The prices for traders and producers were based on the world kernel price and the domestic industry's processing costs rather than the world price for raw cashew nuts in order to ensure that the processing factories could remain competitive in the processed cashew market. According to Deloitte and Touche (1997), the producer price was 50\% of the government-established factory gate price. Of the traders' $50 \%$ margin, $15 \%$ was allocated to the retailer and $35 \%$ to the wholesaler.
} 
colonial period, Frelimo (The Front for Liberation of Mozambique) continued to regulate the cashew industry. Around the time raw cashew exports were banned, the State Secretariat of Cashew (SSC), the central body controlling the cashew industry, and Caju de Moçambique, the holding company for the state-owned processing factories, were established (Nomisma, 1994).

During the colonial period, internal marketing was performed primarily by Portuguese or Asian traders. Like producer prices, traders' margins were highly regulated. As a result, the marketing system was very stable. However, according to Tarp (1990), with Independence in 1975, the existing marketing system broke down as most of the Portuguese traders or "cantineiros" left the country and the Asian traders migrated to urban areas and gave up trading activities. Consequently, the cashew export trade was brought under control of ENACOMO, a state trading company, although private traders continued to act as buying agents (Jaffee, 1995 and Tarp, 1990). Producer prices and trading margins continued to be established by the government and - as previously mentioned - a ban on exporting raw cashews was imposed.

Relaxation of government control of the cashew sector began in the late 1980s when Mozambique entered into its first structural adjustment program with the World Bank. ${ }^{4}$ This program (the 1987-1990 Economic Rehabilitation Program or ERP) was aimed at decreasing overall administrative controls in order to restore market incentives to promote production and trade (Tarp, 1990). While it was not specifically focused on the cashew industry, it covered the cashew sector along with other products and sectors of the economy (Pomerantz, 2001b). Among other things, the program called for a substantial increase in the government-established producer price and the establishment of the minimum producer price system that was implemented in the early 1990s.

In its 1995 Country Assistance Strategy (CAS) Report, the World Bank required Mozambique to liberalize cashew marketing and exporting in order to satisfy the "base case" conditions and qualify for approximately $\$ 400$ million of loan assistance (World Bank, 1995a). ${ }^{5}$ However, according to the World Bank's former Mozambique Country Director Phyllis Pomerantz, there was no specific "conditionality" (Pomerantz, 2001a). In addition to recommending that Mozambique liberalize cashew marketing, the World Bank also recommended as a subsequent step that it privatize the processing industry. According to Pomerantz (2001a), the government did not follow this advice and privatized the industry before it liberalized cashew marketing.

The World Bank's advice to liberalize Mozambique's cashew industry was based on a 1995 report by Hilmar Hilmarsson, a World Bank consultant (Pomerantz, 2001a and Arulpragasam, 2001). This report was included as a chapter in the 1995 World Bank Report entitled, "Mozambique: Impediments to Industrial Sector Recovery" (World Bank, 1995b). Based on the comparison with other countries and the technology employed, the chapter

\footnotetext{
${ }^{4}$ Mozambique became a member of the Bretton Woods Institutions in 1984.

5 The World Bank's proposed lending program for FY96-00 included low and base scenarios. Liberalizing the cashew industry was a condition for the latter, in which it would receive a loan package of $\$ 665$ million. Under the former, the loan package would be reduced to $\$ 240$ million.

${ }^{6}$ When citing World Bank (1995b) we are also referring to the findings of the Hilmarrson Report.
} 
concluded that the Mozambican processing industry, as structured in 1994, was unviable (World Bank, 1995b). It assumed that liberalization would increase the producer share of the FOB price to $50-70 \%$ and increase cashew production, export value, and farmers' income, as illustrated in Table 1. While the report outlined several policies for improving cashew production and increasing producers' incomes, the World Bank focused on eliminating the export tax on raw cashews. According to World Bank official Johannes Zutt, the World Bank's strategy in advising the Government to eliminate the export tax was to "increase the poverty reducing potential of the cashew industry in Mozambique... and this was one of the few pro-poor things the World Bank could implement at the time" (Zutt, 2001). According to former World Bank Country Director Pomerantz, the World Bank hoped that there would be sufficient competition at the marketing level to ensure that reducing the export tax would increase the export price and therefore the producer price.

While the Bank and the government agreed that liberalization and privatization were appropriate, they disagreed on the extent and the time horizon for the liberalization. The Bank favored immediate and complete elimination of the tax, while the industry favored a gradual, partial reduction in the tax (World Bank, 2000a). Table 2 illustrates the different proposals, the schedule agreed by the government and the World Bank, and the actual tax rates implemented. We discuss some of the specific reforms below.

\section{Price reforms}

In 1991/92, the export ban on raw cashew nuts was lifted and limited quantities of raw nuts were allowed to be exported. However, a $60 \%$ tax on the difference between the FOB and factory gate prices and a quantitative restriction of 10,000 tonnes were imposed (Desai, 2001). In 1992/93, the tax (on the difference between the FOB and factory gate prices) was lowered to $30 \%$, but the quantitative restriction was maintained at 10,000 tonnes. In 1993/94, the export tax was maintained, but the quantitative restriction was loosened. While the initial export quota remained fixed at 10,000 tonnes, additional quantities were auctioned off in 5,000-tonne lots to registered exporters. In 1994/95, the quantitative restriction was lifted and the export tax was reduced to $20 \%$ of the FOB value in 1995/96 and then 14\% in 1996/97 and 97/98 (Deloitte and Touche, 1997 and Desai, 2001a). Faced with domestic opposition to the reductions of the export tax, Mozambique's parliament passed a bill in 1999 that increased the tax to between 18 and $22 \%$, the exact amount to be determined each year, depending on market conditions. (EIU, March 2000). In both the $1999 / 00$ and 2000/01 seasons, the export tax was 18\% (Desai, 2001a).

Producer prices were significantly increased in 1987/88 from 10 Meticais $/ \mathrm{kg}$ to 105 Meticais $/ \mathrm{kg}$. Also at this time, the government announced that a minimum producer price would replace the fixed producer price as the liberalization program progressed (Tarp, 1990). As illustrated in Figure 2, the government continued to significantly increase the minimum producer price throughout the 1990s until 1998/99 when it was fully liberalized. During this period, there was near parity between the actual nominal producer price and the government-established

minimum price. During the period of the export ban, the government also fixed the "factory gate price" or the price processors paid for their raw nuts. Government control over prices paid by the processing industry for raw nuts were eliminated at the time of privatization, 1991.

\section{Marketing reforms}


Liberalization of the cashew industry also led to significant changes in the marketing system. The state trading company, ENACOMO, was privatized in the late 1980s. Additional marketing channels opened in 1991/92 when the ban on exporting raw cashews was lifted. According to the current Mozambique Country Economist for the World Bank, Peter Moll, the rationing arrangement for export licenses was eliminated. Under that rationing arrangement, individuals had been required to apply for export licenses and one of the criteria for obtaining a license was that the individual "had previously been a recipient of such a license" (Moll, 2001). Exporters are, however, still required to be licensed by the State Secretariat of Cashew (Desai, 2001a).

\section{Privatization}

Privatization of Caju de Mozambique - the holding company of the state-owned processing factories - began in 1991 when a privatization unit (UTRE) was created within the Ministry of Finance (World Bank, 1995b). By the end of 1994, all of the formerly state-owned factories had been privatized. As shown in Table 3, the majority of factories were sold to local entrepreneurs and not to foreign investors (as suggested by Krugman, 2000). In 1995, the only disappointing aspect of the privatization appeared to be the revenue generated. According to Deloitte and Touche (1997) the factories were all sold at below asking price and payments made totalled $\$ 850$ thousand (compared with the $\$ 13.5$ million the government had asked for). Between 1995 and 1998 six new factories were established, with an installed capacity of 8,950 tonnes and full-capacity employment of approximately 1,200 workers. ${ }^{7}$ These newer factories supply the domestic and regional market, and not the traditional international market. ${ }^{8}$

The fact that the government privatized the factories under a regime of protection and subsequently began to remove that protection put the industry up in arms. On James Wolfensohn's first visit to Mozambique in 1997, he was approached by angry industrialists who claimed that the World Bank was responsible for the problems the industry was having procuring raw cashew. Wolfensohn responded by authorizing another study of the cashew industry in Mozambique (Deloitte and Touche, 1997), which came out in favor of protecting the processing factories for some period of time. Subsequently, at least two additional studies have been commissioned by the government, also paid for by the World Bank. Abt Associates performed a third analysis of the processing industry (Abt Associates, 1999) and Jaikishan Desai performed an analysis of cashew farmers (Desai, 2001a).

\section{A Simple Analytical Framework}

We present here a simple conceptual framework to facilitate the evaluation of the liberalization. The framework tracks the incomes of the following distinct groups: (i) raw cashew producers (farmers); (ii) traders and other intermediaries; (iii) owners of the cashew processing factories; (iv) workers employed in the factories; and (v) the government.

Raw cashew producers face the farmgate price $p_{1}$ and produce both for home consumption and for the market. We denote own consumption by $z$ and the marketed production by $q$. Since total output is $q+\mathrm{z}$, total costs are given by $c(q+z)$. Farmers also consume an

\footnotetext{
${ }^{7}$ Based on 130 workers per tonne of raw nuts processed and 2 shifts per day (Abt, 2000).

${ }^{8}$ Cabo Caju is an exception to this domestic and regional focus. It has a contract to supply Delta Café, an international distributor.
} 
"outside good" $z$ ', whose price we fix to unity. Let farmers have the quasi-linear utility function given by $u^{f}=u\left(z, z^{\prime}\right)=z^{\prime}+v(z)$. They select $z, q$, and $z^{\prime}$ by maximizing this subject to the budget constraint $p_{1} q=z^{\prime}+c(q+z)$. Substituting the budget constraint into the utility function, the farmers' utility can also be expressed as $u^{f}=v(z)+p_{1} q-c(q+z)$, which is an expression involving only $z$ and $q$. We shall use this expression below to summarize cashew growers' welfare. The associated first-order conditions are $v^{\prime}=c^{\prime}$ and $p_{l}=c^{\prime}$.

The world (FOB) price of raw cashew is $p^{*}$, and the after tax FOB price is $p^{*}(1-t)$. Domestic intermediaries earn the rents that arise between the farmgate price and the after tax FOB price, $\left[p^{*}(1-t)-p_{1}\right] q$. Domestic processors use raw cashew and labor to produce processed cashews for the world market. Let $P^{*}$ and $w$ stand for the world price of processed cashews and the wage earned by factory workers, respectively. Then the profits of the domestic processors can be expressed using the profit function $\pi\left(P^{*}, w, p^{*}(1-t)\right)$, with the standard properties: $\frac{\partial \pi}{\partial P^{*}}=$ $X$ (total supply or exports of processed cashew), $-\frac{\partial \pi}{\partial w}=l$ (labor demand), and $-\frac{\partial \pi}{\partial p^{*}(1-t)}=q_{d}$ (input demand for raw cashew nuts). Exports of raw cashew $(x)$ are the difference between the total marketed supply and the demand from domestic processors: $x=q-q_{d}$.

Urban workers earn the wage bill $w l$. We let $w_{o}$ denote the social opportunity cost of their labor. If unemployment is their next best alternative, $w_{o}$ will be approximately zero. The social surplus generated by employment in the domestic processing industry is therefore given by $\left(w-w_{0}\right) l$.

We are now ready to express the total social surplus generated by the cashew industry, which is the sum total of the incomes that accrue to each of these groups (plus the government, which receives export tax revenues). We write this as follows:

$$
U=\pi\left(P^{*}, w, p^{*}(1-t)\right)+\left(w-w_{0}\right) l+\left[p^{*}(1-t)-p_{1}\right] q+\left[v(z)+p_{1} q-c(q+z)\right]+t p^{*} x
$$

The five terms on the right hand side represent owners of the processing factories, urban workers, traders/intermediaries, cashew growers, and the government respectively. Note that since $\pi\left(P^{*}, w, p^{*}(1-t)\right)=P^{*} X-w l-p^{*}(1-t) q_{d}$, this expression can also be written as

$$
U=\left(P^{*} X-p^{*} q_{d}\right)-w_{0} l+p^{*} q+v(z)-c(q+z) .
$$

This shows that the total surplus consists of value added in the processing industry at world prices (the term in parentheses) net of the social opportunity costs of the labor employed there, plus the total value added generated by the raw cashew sector (again at world prices). We emphasize that this framework is perfectly general; in particular, it can handle the possibility that the processing factories were generating negative value added at world prices (as some observers have claimed), in which case the first term on the right-hand side would be negative, but otherwise the analysis would remain unchanged. 
Consider now a small perturbation that arises, say, from a change in the export tax $t$. Differentiating equation (1) totally, rearranging terms, and simplifying, ${ }^{9}$ we get the following expression:

$$
\begin{aligned}
& \frac{d U}{d t}=\quad t p * \frac{d x}{d t} \quad \text { (export-quantity effect) [1] } \\
& +x \frac{d p^{*}}{d t} \quad \text { (terms-of-trade effect) [2] } \\
& +\left(w-w_{0}\right) \frac{d l}{d t} \quad \text { (unemployment effect) [3] } \\
& +\left[p^{*}(1-t)-p_{1}\right] \frac{d q}{d t} . \quad \text { (traders' margin effect) } \quad[4]
\end{aligned}
$$

The welfare change associated with the reduction in $t$ can be decomposed into the four components shown above. First, we have the standard efficiency gain arising from the increase in the quantity of raw cashew exports (channel [1]). Since the export restriction artificially represses such exports, a reduction in $t$ enhances welfare insofar as it spurs exports of raw cashew nuts (i.e., as long as $d x / d t<0$ ). In the absence of any other market distortions, policyimposed or otherwise, this would be the only operative channel and the only term on the righthand side.

The remaining three terms capture additional complications that are relevant to the Mozambique case. The terms-of-trade effect (channel [2]) tracks the possibility that increased exports of raw cashew may depress the FOB price received by the exporters $(d p * / d t>0)$. While Mozambique has only a small share of the world market for raw cashews, it faces a monopsony buyer in India. (India or any other country does not have similar market power vis-à-vis Mozambique in processed cashew. Therefore we have assumed $d P * / d t=0$.) We shall discuss this issue further in section 6.

The possible unemployment costs of the liberalization are depicted in the third term on the right-hand side (channel [3]). As long as there is a gap between wage earnings in the processing industry and the social opportunity cost of employing labor, a reduction in factory employment associated with the reduction in the export restriction $(d l / d t>0)$ is welfare reducing. (Of course, the framework does not rule out the possibility that these losses are more than offset by the income gains that result from reorienting raw cashews to export markets.)

Finally, channel [4] is the consequence of imperfect competition at home, namely the bargaining leverage that traders and other intermediaries may have on cashew growers. This leverage creates a gap between the after tax FOB price of raw cashew and the farmgate price. The cost is an undersupply of raw cashew to the market. The (partial) undoing of this as a result

\footnotetext{
${ }^{9}$ Note in particular that the terms in $d z, d w, d p_{I}$ and $d t$ drop out, either because of market-clearing conditions or first-order conditions associated with utility and profit maximization.
} 
of the reduction in the export restriction represents an independent source of efficiency gain for the economy $(d q / d t<0)$.

These effects relate to the aggregate efficiency costs and benefits, and sweep aside distributional outcomes. In other words, all the components of income are weighted equally in the overall balance sheet. However, the impact on farmers is of particular concern, as a key objective of the liberalization policy was to reduce poverty in rural areas. To trace the effect of the policy on farmers, we can use the expression developed above for farmers' utility: $u^{f}=v(z)+$ $p_{1} q-c(q+z)$. From the envelope theorem, $d u^{f} / d t=q\left(d p_{1} / d t\right)$. This represents the standard result that the cashew growers become better off when the farmgate price of raw cashews rises $\left(d p_{1} / d t\right.$ $<0$ ), and that the increase in their welfare is proportional to the net quantity supplied to the market. Note that the benefits are proportional to the commercialized part of cashew production - not the total harvest.

We shall discuss each of these effects in greater detail below, presenting evidence on the extent to which the channels in question were operative. We shall also provide, where possible, some rough estimates of the quantitative magnitudes involved (using non-infinitesimal versions of the expressions above). In particular, section 4 provides an estimate of the aggregate effect of channels [1], [2], and [4], while section 7 provides an estimate for channel [3]. Sections 5 and 6 provide a more extended discussion on the likely significance of domestic and external imperfect competition (channels [2] and [4]).

\section{Evaluating the Efficiency Gains from Reducing Export Restrictions}

The policy environment surrounding the cashew industry has evolved significantly since the liberalization process began in 1987. Controls on raw cashew exports have been gradually removed. The government no longer fixes producer prices or factory gate prices. More traders have been licensed and the state-owned cashew factories have been privatized. In what follows, we evaluate and estimate the direct efficiency gains and distributional consequences associated with these reforms.

Results of these reforms have so far been mixed. The real producer price nearly doubled between 1990/91 and 1999/00, but then dropped sharply in 2000/01 to its lowest level since 1994/95. As Figure 3 shows, the producers' share of the FOB price also increased throughout the 1990s. But in spite of the increase in producer prices, the supply response has been weak and sporadic (see Figure 1). Average output since the time price reforms began has increased relative to the previous decade but only by around 10,000 tonnes - half the 20,000 tonnes envisaged in the World Bank's base case scenario. As for exports, the quantity of raw cashews exported peaked in 1995/96 at 35,320 tonnes.

What about new planting? Cashew is a perennial and Mozambique's cashew trees are reported to be old and in need of replacement. Perhaps farmers have been planting new trees and it is just a matter of time before we observe a vigorous supply response. However, this does not seem to be the case. Less than one quarter of all households are reported to have planted any new cashew trees, and among these households the average number of new trees planted was 3.6 (Desai 2001a). This puts new plantings at roughly one million trees per year, just enough to replace the reported one million trees that die each year (AIM, April 19, 2001). At this rate, 
Mozambique's cashew orchard will never be as it was in the early 1970s when 45 million trees were reported to be productive. ${ }^{10}$

One important bit of evidence related to the supply response is the fact that farmers appear to retain a fairly large proportion of cashew for home consumption. A great deal of uncertainty exists regarding the difference between the quantity of raw nuts produced and commercialized. Deloitte and Touche (1997) estimates that $70 \%$ to $90 \%$ of raw cashews are commercialized and that the remainder is retained for domestic consumption. Regional differences contribute to the uncertainty regarding overall raw cashew production and commercialization. Desai (2001a) found that about $85 \%$ of farmers in the province of Nampula sell some part of their harvest, and that only about $64 \%$ of what they harvest is commercialized. In the southern provinces of Inhambane and Gaza, he found a different pattern: only 14\% and $29 \%$ of harvested cashews are commercialized in these two provinces respectively. Furthermore, in Inhambane, less than one-third of cashew producers sell any part of their harvest, and in Gaza, only about $47 \%$ market any of their harvest. The fact that cashew serves both as a food crop and as a cash crop has important implications for the poverty impact of export liberalization: it indicates that the positive income effect of an increase in raw cashew prices on farmers is substantially smaller than it would have been with full commercialization of the harvest (as shown analytically in the previous section).

Marketing seems to have become more competitive. The number of exporters has more than tripled from 3 in 1990/91 to 11 in 1996/97 (Deloitte and Touche, 1997). ${ }^{11}$ In addition, it appears that a number of informal or unlicensed traders began operating. Prior to the liberalization, the trading system was characterized by more formal, established relations in which farmers sold raw nuts at trading posts to licensed traders. The trader generally had a relationship with a factory or larger traders to whom he would sell the raw nuts. During this period, supply chain credit was common (Owen, 2001). Following liberalization, the marketing system became more competitive and supply chain credit became less common. Producers increasingly traded with itinerant, informal traders who move into the rural areas earlier in the season and buy in smaller quantities at producers' households. The formal traders have objected to the informal traders who are unlicensed and therefore avoid paying taxes (Owen, 2001).

Although farmers are earning more and output has risen, these results are disappointing and certainly fall short of World Bank projections. The Bank's study of the cashew industry indicated expectations that under the worst case scenario (see Table 1) liberalization of cashew marketing would allow farmers to earn $\$ 0.38 / \mathrm{kg}$ for raw nuts (50\% of the projected FOB price), which would increase supply by 20,000 tonnes (to 54.3 from a base of 35 thousand tonnes) and raise farmers' incomes to six times their level at the time of the study or $\$ 24.5$ million. In practice, the average price actually received by farmers since the ban was lifted has been $\$ 0.27 / \mathrm{kg}$ (40\% of the annual average FOB price over 91/92-00/01). Average annual marketed output since the ban was lifted amounts to 44,300 tonnes or roughly 10,000 tonnes more than the annual average in the previous decade (during which the ban was in effect and the country was at civil war). Marketed output still remains much lower than its level immediately following

\footnotetext{
${ }^{10}$ Replanting is reported to have stopped somewhere around 1965 and current estimates put the stock of trees around 27 million (Nomisma 1994, Desai 2001).

${ }^{11}$ More recent estimates put the number of exporters at between 8 and 10 (Matule, 2001).
} 
independence (approximately 90,000 tonnes). Average annual income earned by farmers from selling raw cashew since the export ban was lifted amounts to \$13 million (only half the amount used in the World Bank's worst case medium-term scenario). This compares with an annual average income earned by farmers during the period of the civil war (1982-1992) of \$7.0 million. In addition, over the last two seasons, the nominal farmgate price has dropped by more than $50 \%$ (from $\$ 0.45 / \mathrm{kg}$ to $\$ 0.20 / \mathrm{kg}$ ) and in $2000 / 01$ the real farmgate price was no higher than it was during the last year in which the ban was in effect.

To gauge the overall impact of these reforms on the economy of Mozambique, we compute rough estimates of the net economic-surplus gains associated with these reforms, using observed levels of prices and quantities. We make several assumptions in developing our estimates. We assume that had the ban remained in effect, processors would have continued to pay traders no more than $40 \%$ of the FOB price for raw cashew. This is a very conservative estimate and is based on the original World Bank study of the cashew sector in Mozambique which states that "the factory gate price has also remained low, at about 40 percent of the border price, as traders must first sell the raw nuts to local factories at a "negotiated" price, with the government acting as a referee" (World Bank, 1995b). We also assume that had the ban remained in effect, the quantity of marketed raw cashew would have remained equal to the annual average of marketed surplus during the period of the civil war or 35,000 tonnes. For post-reform prices and quantities, we use the observed averages for the period 1991/92 through 2000/01. Specifically, we take \$671 and \$584 as the FOB and after-tax FOB prices of raw cashew, respectively. The quantities of raw nuts processed and marketed are 21,500 and 44,300, respectively.

To compute the increase in farmer surplus, we assume that had the ban remained in place, farmers would have received no more than $20 \%$ of the FOB price for raw cashew. Again, this is a conservative estimate based on a trader's margin of $50 \%$ and the ability of the trader to obtain $40 \%$ of the FOB price from the factory. At the time the ban was lifted, farmers received approximately $25 \%$ of the FOB price and they currently receive $45 \%$ of the FOB price (see data table in Appendix C). As before, we use the data in Appendix $\mathrm{C}$ to compute annual averages of observed prices and quantities for the period 91/92-00/01. A graphical representation of our calculations is provided in Figure 4.

We can approximate the standard efficiency gain from the removal of the ban with the sum of the areas $i b c$ and mnib in Figure 4, the latter being the tax revenue that accrues to the government. This yields $\$ 5.57$ million $(=0.5 *[584-269] *[44.3-21.5]+[671-584] *[44.3-21.5])$. Of this, $\$ 1.98$ million is government revenue. Note that this $\$ 5.57$ million figure captures both of the channels [1] and [2] discussed in the previous section, insofar as any induced reduction in the FOB price is already reflected in the observed post-ban average price of 671. To this number, we must then add the additional income that accrues to domestic traders/exporters due to the margin between the after tax FOB price and the farmgate price (see channel [4]). This gap is shown in the Figure as the difference between the "supply" curve of the traders/exporters and the marginal cost schedule of farmers. The relevant area is $c b f g$, which is approximately equal to $\$ 2.14$ million $(=0.5 * 134 * 9.5+0.5 * 315 * 9.5)$. Of course, not all of this gap is pure profits or rents. We assume that half of it represents real resource costs (transport, wastage and other real expenses). So we add half of the area $c b f g$ to the number above, for a total efficiency gain (net 
of unemployment costs) of $\$ 5.57+\$ 1.07=\$ 6.64$ million, or $0.14 \%$ of Mozambique's GDP in 2000 .

How much of the surplus generated by the liberalization do the farmers get? The total surplus accruing to the farmers, traders, and exporters of raw nuts is approximately equal to $\$ 13.51$ million--the increase in the price times an average of ban and post-ban quantities (or [584-269][44+35]*0.5 = \$12.44 million) plus one half the traders' margin (\$1.07 million). Of this only a part goes to the farmers themselves. The change in farmer surplus associated with the removal of the ban is approximately equal to the increase in the producer price times an average of ban and post-ban quantities. The resulting annual average increase in producer surplus for farmers amounts to $\$ 5.29$ million--([268-134]*[35+44]*0.5)--or roughly $\$ 5.29$ per cashew growing household per year. This is less than four days' wages at the minimum Mozambican wage of $\$ 1.65$ per day.

The result that the gains to farmers are so small, despite our generous assumption that farmgate prices have doubled, is the product of two factors. First, raw cashew production is and remains quite depressed, relative to historic norms. Second, farmers retain part of their harvest for own consumption. These two factors together imply that the share of cash income form raw cashew in household budgets is on average quite small-less than 5 percent. ${ }^{12}$ Of course, there are important regional variations that need to be taken into account when assessing the impact on farmers' welfare. Cashew is a much more important source of income for farmers in Nampula than it is in other regions. So farmers in Nampula have benefited more than farmers elsewhere. The overall impact, however, seems to have been quite small.

Finally, the loss in consumer surplus that accrues to industrialists is equal to $\$ 8.90$ million or the price increase times an average of ban and post-ban quantities (-(584$\left.269)(35+21.5)^{*} .5\right)$. Note again that this does not take into account the losses associated with unemployment. We discuss this in detail in section 7 of the paper.

Therefore, the bottom line is as follows. Even assuming all unemployment away, the liberalization of raw nut exports has cost cashew processors $\$ 8.9$ million on an annual basis. The bulk of the benefits have accrued to traders and exporters of raw cashew, who have gained about $\$ 8.2$ million (=13.5 - 5.29). The government itself has gained about $\$ 2.0$ million in export tax revenue. The farmers themselves have received only $\$ 5.3$ million.

\section{The Role of Market Structure: Internal Marketing}

The calculations above suggest that the gain accruing to the farmers has been quite small. One reason for this is that cashew growers receive only around 40-50 percent of the after tax border price, with much of the rest going to local and regional traders. Despite the increase in competition among traders in recent years, it is clear that the marketing channels for raw cashew

\footnotetext{
${ }^{12}$ In the three provinces that he surveyed, Desai (2001) found that cash income from cashew nuts averaged 230,000 Mts. per household (Table 3.27). According to his estimates, total real consumption expenditures per capita stood at around 1,800,000 Mts. (Table 3.13). Assuming five persons per household, the share of cash income from nuts in total consumption expenditures is about $2.6 \%$.
} 
remain imperfectly competitive. Farmers' income are depressed not only by transport and marketing costs, but also by the market power exercised by traders.

The internal marketing of cashew is performed through a multi-tiered trading system. While the system is currently evolving in response to market and regulatory changes, there is essentially three layers of intermediation between cashew farmers and world markets: (a) local buyers and small retail traders; ${ }^{13}$ (b) larger wholesale traders; and (c) exporters and the domestic processing factories. This is shown schematically in Figure 5, which summarizes the key players and the flow of cashews through the marketing system in 1997/98. The producers who marketed approximately 52,000 tons of raw cashews in 1997/98 sit at the bottom of the system. They sold 27,000 tons of raw cashews at formal local posts, 15,000 tons to local intermediate cashew collectors, and 10,000 tons to small/retail traders. From the local posts and intermediate local traders, the majority of cashews were then sold to agents informais (informal traders) or agents retalhistas (formal retail traders). Empresas comerciais (large/wholesale traders) and processadores (processors) make up the next tier.

Entry barriers at each of these levels are sustained by a combination of setup costs and regulatory restrictions. For example, an export license is required to export raw nuts, and this requirement is apparently enforced rather strictly (Kottak 2001). For mid-range traders, the licensing requirements are not as significant. While technically one must be licensed, as long as someone is working under an exporter, a license is not actually necessary. However, at the small/retail trader level, one must obtain a license in order to set up a trading post and scales within a given district. Small traders have to purchase this license from the district administrator for a fee of approximately $\$ 20^{14}$ (Kottak, 2001). In addition, the elimination of the governmentset reference price may have aggravated asymmetric information. Prior to liberalization, the government reference price was apparently clearly communicated. Since then, according to Dan Owen (2001), there has often been "massive" confusion regarding prices. ${ }^{15}$ Producers perceive that they had to sell their raw nuts early in the season. As a result, the itinerant traders who approach the producers can have significant market power (Owen, 2001).

For both small and large traders, cashews represent only a limited portion of their trading activities. According to Deloitte and Touche (1997), USAID found that cashew accounts for some $10 \%$ of retailers' overall business. Cashew trade is concentrated during the months of November through February. Like producer prices, traders' prices vary within a season. See Table 4 for a history of trading margins based on the Deloitte and Touche (1997) and World Bank (1995b) reports. We provide more details on each tier of the marketing structure below.

\section{Small rural trader/retailer}

There is generally one local post per village, if any, and therefore there is very little competition at this level. While local informal and intermediate cashew collectors have penetrated into some of the rural areas, there is still very limited competition and the majority of

\footnotetext{
${ }^{13}$ While the primary tiers in the trading system have remained the same, prior to liberalization, the small retail traders were solely formal traders. Since liberalization, informal small traders have also entered the trading system.

${ }^{14}$ It is unclear whether this is per village/scale or 1 per district.

${ }^{15}$ According to Phyllis Pomerantz, World Bank Country Director, Mozambique did not announce the 5-year schedule for eliminating the export tax, thereby increasing the level of uncertainty (Pomerantz, 2001a).
} 
producers have only one trader to whom they can sell their raw nuts. The informal traders and small retail traders generally buy cashews from approximately 5-8 local posts. They typically handle 5-12 tonnes of cashews. They are licensed and are required to pay a 3\% circulation tax (Deloitte and Touche, 1997). Small traders purchase cashew through barter (exchanging basic foodstuffs and required farming inputs for cashew nuts) and, increasingly, through cash transactions. $^{16}$

According to Deloitte and Touche (1997), the informal/unlicensed traders (ambulantes) have increased in number since liberalization. Informal/unlicensed traders are itinerant traders who often have their own transport vehicles and therefore are able to travel to production areas or posts located near production areas. It is difficult to estimate the number of informal traders. However, in certain areas, they may exceed the number of formal traders. Informal traders will usually only buy with a specific market in mind and are often connected with the larger traders and exporters who may advance them the necessary money or goods to buy the cashews. They have lower costs of business because they do not have to rent trading posts, do not pay the licensing fee, and generally evade taxation. In the case of both the formal and informal traders, the cost of transporting the raw nuts to the large trader/wholesaler is significant, due to the poor rural infrastructure (Deloitte and Touche, 1997).

\section{Large trader/wholesaler}

Large traders/wholesalers are located in larger towns or on key trading routes. In contrast to the retailers, there are fewer wholesalers, but they are well organized and financially very strong (World Bank, 1995b). The large traders do not compete against each other, but rather seem to have an overall area of operation (Owen, 2001). Entry is primarily limited by the high official cost of working capital that bears an interest rate of approximately fifty percent. Large traders generally have long-established businesses with close working relationships with retailers (Deloitte and Touche, 1997). Large traders or wholesalers vary greatly in size (trading between 50 and 400 tonnes of cashews), and scope of trading activity (Kottak, 2001).

\section{Exporters}

According to Matule (2001), there are 8-10 cashew exporters in Mozambique who are all based either in Maputo or Nacala, the primary port in Nampula Province. Each exporter generally sources raw nuts through established relationships with mid to large-scale traders/wholesalers (Kottak 2001). It appears that the main exporters attempt to roughly fix the purchase price at the beginning of each year (Kottak, 2001, Mooney, 2001b).

According to Deloitte and Touche (1997), the exporters have a great deal of market power. They found that,

In Nampula Province there is considerable overlap between the different levels of traders, especially at the wholesaler/exporter level, where the same companies are operating. This, combined with the long-term links between the wholesalers and some of the retailers places the exporter in a very strong position regarding the purchase of the raw nuts. This position has been weakened slightly over the last three years, especially by the

\footnotetext{
${ }^{16}$ Deloitte and Touche (1997) and Kottak (2001). Nicholas Kottak worked as a trader in Nampula during the 1998/99 season.
} 
arrival of the unofficial traders, but is still significantly stronger than the position held by the factories.

According to the World Bank (1995b), the trading margin between the farm-gate and factory gate price is generally approximately $50 \%{ }^{17}$

\section{Linkages among large traders, exporters, and processing factories}

Several trading corporations engage in large-scale trading, exporting raw cashews, and also processing kernels. For example, Gani is a large trading company. It owns shares of Angocaju, CC-Nacala, and Inducaju processing factories and has been one of the leading exporters of raw cashew nuts for the past several years (Abt Associates, 1999). According to Matule (2001), there are approximately 80-100 large traders and that the majority of these traders are directly linked to the $8-10$ exporters. ${ }^{18}$

\section{The analytics of price pass-through in the presence of multi-tiered marketing}

It is a standard result in the theory of industrial organization that vertical relationships magnify the costs of imperfect competition when the units within the relationship act independently. This is the "double-marginalization" problem, arising from the piling of two distortions on top of each other (see for example Tirole 1988, 173-176). In the cashew case, we have at least three layers, and hence a case of triple-marginalization. Because of the multiplicative nature of these distortions, the implications for prices received by farmers can be particularly severe.

To see this, consider the following simple model. Let there be three stages in the marketing chain, with associated prices $p_{1}, p_{2}$, and $p_{3}$. At each stage, we assume that buyers have monopsony power while the sellers behave competitively. Hence in the first stage, farmers act as competitive suppliers of raw cashew, with the positively sloped supply function $Q=Q\left(p_{1}\right)$ and associated price elasticity of supply $\varepsilon$. They face $n_{1}$ small traders who determine $p_{1}$ in NashCournot fashion. Successive stages are analogous. Small traders face $n_{2}$ large traders (who determine $p_{2}$ ), while large traders face $n_{3}$ processors/exporters who determine $p_{3}$. The (exogenous) post tax world price is $p^{*}(1-t)$. We ignore transport and other costs, to focus purely on imperfect competition. Under these assumptions, the ratio of farm-gate price to border prices can be expressed simply as:

\footnotetext{
${ }^{17}$ However, as Table 4 illustrates, the trading margins increased in 1993/94 when exporters' margins reached 482.3\% (World Bank, 1995b). This report notes that in 1993/94 Caju de Moçambique was "being paralyzed pending its privatization and only one private factory was operating" and "wholesalers were able to export nuts directly to India where they could more than double the price obtained from Mozambican factories" (World Bank 1995b).

${ }^{18}$ Other trading companies involved in large-scale trading, exporting and processing include Joao Ferreira dos Santos (JFS), which owns Cajeba processing factory; Has Nur, which owns Mocaju processing factory; and Enacomo, the former state trading company which is currently a holding company that owns the Angocaju processing factory. Further, Olam, Casa Salvador (Kottak 2001), C.C. Gordhandas Valabhdas, S.A.R.L., and Ludwig Mueller (Mooney 2001b) participate in both trading and raw cashew exporting. The source for this data is Abt Associates (1999), unless otherwise noted.
} 


$$
\frac{p_{1}}{p^{*}(1-t)}=\left(\frac{n_{1} \varepsilon}{1+n_{1} \varepsilon}\right)\left(\frac{n_{2} \varepsilon}{1+n_{2} \varepsilon}\right)\left(\frac{n_{3} \varepsilon}{1+n_{3} \varepsilon}\right) \text {. }
$$

This expression clarifies the multiplicative nature of the distortion, and the steep discount suffered by farmers as a result of the multi-tiered nature of the market. (Note that the price passthrough increases with the degree of competition at each stage. In the limit, if $n_{1}=n_{2}=n_{3} \rightarrow \infty$, $p_{1}=p^{*}(1-t)$. It also highlights the fact that increasing the degree of competition at any one stage of the marketing chain will not get farmers a much higher share of the world price. For example, even if there are thousands of small and large traders, if these traders only have access to a handful of exporters - say three - farmers will only get around $40 \%$ of the world price. Similarly, if it were true that farmers only had access to one small trader (as suggested by the Deputy Director of INCAJU), then farmers would never get more than $20 \%$ of the border price irrespective of the number of large traders and exporters. (We take $\varepsilon=0.25$, the supply elasticity associated with the medium-term scenario reported in World Bank (1995b)).

The expression also makes it clear that farmers' welfare and hence the overall impact of the liberalization is intricately tied to the number of traders. Note that the number of traders that is relevant in determining the farmers' share of the world price is the number of traders the seller effectively has access to rather than the total number of traders in the country. This level of detail is difficult to come by. However, using data on average actual margins for the 97/98 season and a supply elasticity of 0.25 , we compute the implied number of traders at each stage of the marketing chain as: $n_{1}=11, n_{2}=16, n_{3}=18$ with farmers getting 48 percent of the final price. Based on anecdotal evidence, these numbers appear somewhat on the high side. Part of the explanation for this may be the fact that we are using a farmgate price average. According to Desai (2001), farmgate prices within a given year vary widely. For example, during the 97/98 season, Desai (2001) found that roughly one-third of all farmers received no more than $\$ 0.26 / \mathrm{kg}$ for raw cashew or $35 \%$ of the world price with some receiving as little as $\$ 0.17 / \mathrm{kg}$ or $24 \%$ of the world price. Using these farmgate prices instead of the seasonal average brings the number of effective traders faced by the farmer to between 2 and 5 .

A fuller evaluation of the impact of imperfect competition would need more detailed information on prices, numbers of traders, and the nature of strategic behavior. Nevertheless, this exercise illustrates the relative inefficacy of price reforms in poverty alleviation when these reforms focus on markets far removed from those that farmers actually transact in.

\section{The Role of Market Structure: International Trade}

Critics of the liberalization process in Mozambique have argued that because of "unfair trade," Mozambique must act strategically and devise an industrial policy aimed at promoting the cashew sector. ${ }^{19}$ Claims of "unfair trade" can be boiled down to two: (1) India has monopsony

\footnotetext{
${ }^{19}$ For example, the Deloitte and Touche (1997) study argues that "if the disadvantages faced by Mozambique because of India's trade policy are not countered with an export tax on raw nuts, processors will be faced with unfair competition that will have far reaching consequences for the economy of Mozambique." According to UNDP (1998: $64,72,73$ ) 'if Mozambique pursues a free trade policy in marketing raw nuts, within a short period it will cease to have a competitive processing industry.' Instead, 'the Mozambican government should learn from the industry supports offered to, for example, Indian cashew processors, and should adopt similar measures.' Similar concerns are echoed by ordinary Mozambicans. In a recent study by Patrick Nicholson (2002) several interviewees expressed
} 
power in the purchase of raw nuts; and (2) other countries including India subsidize processed cashew exports. From an economic standpoint, the latter is an argument that strengthens the case for liberalizing exports of raw nuts, unless one is prepared to make a case that there are substantial rents in world trade in processed cashew. After all, if India is subsidizing its processing industry, that can only be good news for suppliers of raw nuts such as Mozambique. So we focus here on the claim that India has monopsony power in the market for raw nuts.

Monopsony power on the part of India would lower the price that Mozambique earns for its raw nut exports. On the assumption that the market for processed nuts is relatively competitive, exporting raw nuts (instead of processed nuts) then entails a net terms of trade loss for Mozambique. In addition, India's monopsony power leaves Mozambique in a vulnerable position vis-à-vis India should India's need for raw nuts from Mozambique decline. In fact, India's eighth national development plan calls for self-sufficiency in the production of raw cashew. Even if India does not achieve this goal, the concern is that the increase in supply will push down the price that Mozambique can obtain for its raw nuts. In the event that India does achieve this goal, Mozambique will have to look for another outlet for its raw nuts. We review in this section the structure of international trade in raw and processed cashew. We also document what we know about the Indian government's policy vis-à-vis its cashew sector.

\section{The world cashew market}

Purchases of raw cashew have historically been dominated by India. Between 1990 and 2000 , India bought $84 \%$ of the world's raw cashew, followed by China (4\%) and Singapore (4\%) (see Table 5). The Hirschman-Herfindahl Index (HHI) on the buyer's side of the market is 7,069, indicating a very high degree of monopsony power. By contrast, sales of raw cashew are much less concentrated. Throughout the 1990s, Tanzania sold $32 \%$ of the world's raw cashew followed by Guinea-Bissau (14\%), Vietnam (14\%), Indonesia (10\%) and Cote d'Ivoire (9\%). The HHI on the seller side of the market is $1,671 .^{20}$ Although Mozambique shows up as exporting no raw cashew in the FAO statistics, several other sources (Deloitte and Touche 1997, Abt 1999, INCAJU 2001) report that Mozambique exported approximately $10 \%$ of the world's raw cashew over the last decade.

Table 6 indicates that there is much less asymmetry between buyers and sellers in the world market for processed cashew. There are similar levels of concentration on the two sides of the market, with the HHI for imports and exports at 2,377 and 3,443, respectively. Although the market for processed cashews is moderately concentrated, neither side has the unilateral market power that India has in the purchase of raw cashew. Imports of processed cashew over the period 1990-2000 have been dominated by the United States (34\%), with India following closely $(32 \%)$. India (52\%) and Brazil (22\%) dominate on the sellers' side, with Mozambique's share standing at a paltry $2 \%$.

concern over what they believed to be strategic behavior on the part of Indian traders. In their view, Indian traders were out to close down factories in Mozambique by paying inordinately high prices thus making it impossible for the Mozambican factories to compete. Now that virtually all of the factories have closed, the Indian traders can get away with paying very low prices.

${ }^{20}$ According to the United States Department of Justice, an index between 1,000 and 1,800 indicates moderate concentration while an index above 5,000 indicates highly concentrated. 
To better understand Mozambique's position in these world markets, we examine bilateral trade statistics for Mozambique (Feenstra, 2000). The main disadvantage of this dataset is that it does not distinguish between raw and processed cashew. Nevertheless, we are able to draw some conclusions from the data, since between 1980 (the start of the dataset) and 1991 Mozambique did not export any raw cashew. ${ }^{21}$ Table 7 suggests that India is the only outlet for Mozambican raw cashew while there are several countries that import processed cashew from Mozambique. According to these data, India did not import cashews from Mozambique until 1991 when the Government of Mozambique lifted the ban on exporting raw cashews. Until this time, the United States and Western Europe were the largest importers of Mozambican cashews. In 1990, the year just before raw cashew exports were allowed, Mozambique exported processed cashew to 15 countries. The United States imported 76\% of Mozambique's processed cashew while Europe accounted for the remainder. Table 7 also highlights the fact that the value of exports peaked during the early 1980s (Feenstra, 2000).

In contrast to India where a significant share of kernels produced are sold domestically, nearly all of Mozambican processed cashews are exported. Although historically the United States and Western Europe have been the largest outlets for Mozambique's processed cashew, this may be changing albeit slowly. New, smaller-scale cashew processing factories are increasingly focusing their attention on the domestic and regional market, particularly Maputo and South Africa (Mooney, 2001a). However, it is estimated that only 2-5\% of kernels produced are sold on this domestic and regional market (Abt Associates, 1999).

These statistics make clear that by moving away from the export of processed cashew and more heavily into the market for raw cashew, Mozambique has placed itself in the weakest possible bargaining position. As an exporter of raw cashew, Mozambique faces essentially a single buyer, India. By contrast, while the market for processed cashew is somewhat concentrated, there is no single dominant player on either side of the market.

\section{Indian cashew policy}

The cashew market in India is both highly complex and highly regulated. India imports both raw and processed cashew and also exports processed cashew. Unlike Mozambique, India has a large domestic market for processed cashews. Estimates regarding the percentage of domestic production that is sold locally range from $25 \%-45 \%{ }^{22}$ Imports of processed cashew have been increasing and in 1996, the value of imported kernels totaled \$194.2 million (UNCTAD, 2001). In addition, the hundreds of processors in India rely to a large extent on

\footnotetext{
${ }^{21}$ The value of exports based on the Feenstra data and the data from Desai (2001a), INCAJU (2001) and FAO (2000) are quite different. During the period in which raw cashew exports were banned, from 1979/80 until 1991/92, the FAO data for the value of kernel exports exceeded the values reported in the Feenstra data. In certain years, the differences were significant. In 1988/89, the Feenstra value of exports was $\$ 9,902,000$, while the FAO value was $\$ 20,022,000$. Differences in the data remain during the period of 1991/92 through 1996/97, the last year of the Feenstra data. During this period, although the differences between sources were significant, for example $\$ 16.6$ million in 1993/94, neither source consistently exceeded the others. Some of the differences in the data may be due to differences in reporting the calendar year versus the seasonal year. However, that would not explain such significant differences entirely.

${ }^{22}$ According to Sampat (2001), approximately $25-30 \%$ of Indian production is sold locally. According to Nomisma (1994), 40-45\% of Indian production is sold on the domestic market.
} 
imported raw cashew. According to Desai (2001c), there are approximately twelve brokers involved in importing and trading raw cashew nuts.

Unlike Mozambique, producer prices in much of India are still regulated. The Indian state of Kerala produces over $50 \%$ of the country's raw cashews. In this state, producer prices and marketing are controlled by the state. The State Cashew Development Corporation and the Cashew Workers' Apex Industrial Cooperative Society (CAPEX) have a monopoly on raw nut procurement within Kerala. They fix producer prices and distribute raw cashews to processing factories through a network of harvest and storage cooperatives (Nomisma, 1994). According to Deloitte and Touche (1997), the state is "reputed to make a steady loss (due to the high prices paid to the farmers which are not totally passed on to the factories) and this loss is periodically written off, effectively representing a subsidy to both the farmers and the processors." Raw nut procurement and marketing are liberalized in the rest of India.

The Indian domestic market for processed cashews is highly protected. India levies a $40 \%$ tariff on imported kernels (UNCTAD, 2001). As a result of this protection, Indian processors sell kernels on the domestic market for a premium compared to the international market rate $^{23}$. This premium is approximately $20-25 \%$ at the retail level and $10-15 \%$ at the wholesale level (Sampat, 2001). According to Deloitte and Touche (1997), Indian processors who produce for export are indirectly subsidized via their ability to sell licenses to import goods free of the normal duty. ${ }^{24} \mathrm{FAO}$ data in Tables 5 and 6 confirm the fact that India is simultaneously importing both raw and processed cashew and exporting processed cashew. This raises the possibility (though difficult to verify) that India is using the proceeds from local sales of processed cashew to subsidize their exports of processed cashew.

Consider for example, the year 2000 in which India paid on average $\$ 0.79 / \mathrm{kg}$ for raw nuts from Mozambique. ${ }^{25}$ India received on average $\$ 5.12 / \mathrm{kg}$ for exports of processed nuts. Using a conversion factor of 4.2 (lower than the usual 5 for Mozambique because shelling by hand has a higher yield), India therefore earned $\$ 1.79$ per $\mathrm{kg}$. of processed nuts before processing costs (\$5.12 minus 4.2 times 0.79). Deloitte and Touche (1997) estimates India's processing costs in 1997 at $\$ 1.82 / \mathrm{kg}$. This implies that India would be losing about 3 cents per $\mathrm{kg}$. of nuts exported. One possibility is that all the raw nuts imported from Mozambique are processed to sell domestically, while local nuts are purchased at a price lower than $\$ 0.79 / \mathrm{kg}$ and processed for export. Alternatively, processors may be able to cross-subsidize exports with local sales. There may be an incentive to do this because of the many perks awarded to exporters by the government of India. Either way, the demand for Mozambique's raw cashew is artificially inflated as a result of Indian trade policy. ${ }^{26}$

\footnotetext{
${ }^{23}$ According to Desai (2001b), Indian domestic sales of kernels are taxed while exports are not taxed. He also asserts that there is a premium on domestic kernel.

24 "Indian export incentives allow for access to import licenses free of the normal $27 \%$ duty for $50 \%$ of the value of the exports. This right can be sold at $15 \%$, effectively giving tax relief of $7.5 \%$ on imports to the full value of the exports" (Deloitte and Touche, 1997, page 55).

${ }^{25}$ None of the following estimates include transport costs.

${ }^{26}$ It is not just India that protects its cashew industry. Brazil bans unshelled cashew nut exports unless special circumstances prevail. And Vietnam and Indonesia have discouraged raw nut exports in order to encourage domestic processing, by imposing export taxes of around 20\% (Vietnam) and 30\% (Indonesia) (Ministry of Tourism, Trade and Industry, 1997).
} 
What about the concern that India may one day no longer need Mozambique's raw cashew? Figure 6 shows a steady increase in Indian raw nut production. In 1980, India produced 180,000 tonnes of raw cashew; in 2001 India's production had reached 450,000 tonnes. In contrast to the steady increase in India's raw nut production, raw nut imports by India have been extremely volatile. A complete picture would also study changes in industry capacity but these figures are difficult to obtain. Nevertheless, the steady increase in India's raw nut production is consistent with India's goal of self-sufficiency in raw nuts and the phasing out of raw nut imports from Mozambique.

\section{Summarizing the evidence - implications for Mozambique}

We have established that India has effective monopsony power in the purchase of raw nuts from Mozambique. We have also shown that the market for processed cashew is more competitive than the market for raw cashew. Thus moving from the export of processed nuts to the export of raw nuts entails a terms of trade loss for Mozambique. Ironically, the liberalization of the export market in Mozambique may have actually increased India's monopsony power. The countries exporting raw cashew to India do not collaborate with each other in setting prices or quantities, and individually their market power vis-à-vis India depends on the number of exporters per country. During the first year that Mozambique exported raw cashew to India, there were only three exporters (Deloitte and Touche, 1997). As a consequence of market liberalization, this number more than tripled and at last count ranged between 8 and 10. This increase in competition at the export level-intended to benefit farmers-reduces Mozambique's bargaining power vis-à-vis Indian importers of raw cashew. ${ }^{27}$

We have also discussed the possibility that India (as well as other countries) may be subsidizing their processing industries. But to return to the point made at the beginning of this section, this would not be in itself an argument for Mozambique doing the same. In fact, ceteris paribus these subsidies, if they exist, raise the price received by Mozambique raw cashew exporters, and increase the cost to Mozambique of discouraging raw cashew exports. Our discussion of the world market for processed cashew suggests that this is not a market where there are likely to be substantial rents. Therefore, on this argument alone, one cannot make a case for Mozambique to encourage domestic processing. The case would have to rest instead on India's monopsony power in raw cashews.

\section{The Domestic Processing Industry: Unemployment Costs}

Mozambique's cashew processing industry is at a standstill. Although accounts vary, most estimates put the total quantity of raw cashew processed in the last couple of years at close to zero (INCAJU 2001; World Bank, 2002).

By 1997, the existing factories employed a total of 10,086 workers (Deloitte and Touche, 1997, Abt 1999). These factories began closing thereafter, and by 2001 none of the highly

\footnotetext{
${ }^{27}$ Note that this may not be an isolated phenomenon. For example, Ghana sells cocoa to three large multinationals. When the Ghana Cocoa Marketing Board was operating, it served as an effective monopolist in the sale of cocoa to these multinationals. Now that the cocoa marketing board has been dissolved, Ghana's bargaining power vis a vis the multinationals has been reduced.
} 
mechanized factories were still operational. ${ }^{28}$ However, it is not just the highly mechanized factories that are having trouble. Cabo Caju, the first semi-mechanical factory to open in 1995 is also reportedly having financial difficulty and Cajeba, another of the semi-mechanical facilities is officially closed. The four factories that remain operational comprise a capacity of 2,450 tonnes and the ability to employ 625 people at full capacity. However, even the four factories that are currently operating are not operating at capacity (World Bank, 2002).

Factory closures have exacerbated a severe unemployment problem in Mozambique. UNDP (2002) estimates that $45 \%$ of the population in Mozambique is currently "economically inactive." Furthermore, unemployment rates are expected to rise with the increase in population. Recent interviews by CAFOD (2002) suggest that whole towns have literally shut down as a result of the closure of the factories. Many of the unemployed are women. Of the 4,214 workers employed by Caju de Mozambique at the time of privatization, 60\% were women. As Penvenne (1997) points out, these women are not the politically powerful urban constituents Krugman refers to in his NYT piece. In addition to wages, many of the factories apparently provided education and care for the children of working mothers (Penvenne, 1997).

There are costs associated with this unemployment, especially since these workers are likely to remain unemployed for some time. The broad societal and political costs of unemployment are difficult to gauge. Easier to get a handle on are the narrower efficiency costs. As long as these workers had a positive social marginal product - and as long as they have not been reemployed - their unemployment entails an overall economic loss to the economy. Of course, in the presence of export restrictions for raw cashews, the social product generated by workers in the factories is uncertain, and can even have been negative. Their wages cannot be used directly as indicators of their social marginal product. However, we have already estimated the economic gains from the redirection of raw cashew away from the processors and toward world markets (section 3). Therefore, any social gain resulting from the reduction in processing activity has already been captured. The loss in the wage bill that is not made up by employment gains elsewhere can then be appropriately treated as a component of the overall cost/benefit calculus (see the analysis in section 3 ).

To compute this loss, we need an estimate of the number of people who lost their jobs as a result of the liberalization. For this, we use the number of employees on the payroll at the time of privatization reported in Abt (1999): 8,091 ${ }^{29}$. This is roughly equal to the number of workers employed in $1997(10,086)$ less those employed in the newer factories $(1,500)$ or 8,586 reported by Deloitte and Touche (1997). It also corresponds roughly with the number of workers that would have been required to process all of the marketed raw cashew had it not been exported. ${ }^{30}$ It is somewhat lower than the 9,900 reported by AIM which likely included workers laid off

\footnotetext{
${ }^{28}$ As illustrated in Table 3, 14 of 18 factories have ceased operations since 1997. Four processing factories are currently operational (Abt Associates, 1999, Mole and Weber, 1999, AIM, 2001, INCAJU, 2001b, World Bank 2002).

${ }^{29}$ This includes both employees on the payroll of the state-owned enterprises and those on the payroll of the factories that were never officially "owned" by the government.

${ }^{30}$ Based on the "base case scenario" in Abt (1999) which reports the number of workers required to process 1,000 tonnes of raw nut by technology type, (130 impact, 175 Oltremare and 240 semi-mechanical).
} 
from the newer factories. Assuming an annual average wage equal to $\$ 750$ a year, ${ }^{31}$ the efficiency loss associated with the loss of 8,091 jobs amounts to $\$ 6.07$ million.

We note that this understates the overall level of unemployment in the cashew processing industry. Since several of the newer factories are currently not operating and because the workers at the newer factories are hired on a temporary basis, when the factories are not operating the workers don't get paid. Nevertheless, unlike the larger mostly mechanical factories, the hope is that these newer factories will reopen. At any rate, conceptually it does not make sense to include these workers in our calculation of the efficiency loss associated with liberalization since these jobs were created post-liberalization.

\section{Reasons cited for "failure" of the cashew processing industry}

To the owners of the large-scale processing factories, the export tax reduction is the primary reason for the industry's failure. But according to many others, these highly mechanized factories were doomed to failure. In its original report, the World Bank asserted that the Mozambican processing industry had a "fundamental structural competitive disadvantage because of the technologies employed" (World Bank 1995b). In 1993, 97\% of installed processing capacity used either impact or Oltremare technology. According to the World Bank (1995b), these highly mechanized processing technologies yielded a relatively low proportion of whole kernels. ${ }^{32}$ Because of the technical limitations of the Mozambican processing system and the substantial price differences between whole kernels and broken kernels (reaching as high as $50 \%$ per unit), the World Bank claimed that the value added by the Mozambican processing industry was marginal or negative in the early 1990s, as illustrated in Table 8 (World Bank 1995b). ${ }^{33}$ The Bank concluded that more labor intensive technologies similar to those employed in India would be more appropriate for Mozambique (also raising the possibility of temporary protection using the "infant industry" argument).

In India, processing is performed predominantly by home-based individual workers who are compensated on the basis of whole kernel yield. Shelling is done by hand with a hammer or with pedal-operated shears (Nomisma, 1994). ${ }^{34}$ While the manual technology employed in India

\footnotetext{
${ }^{31}$ Based on data in the Abt report suggesting that production workers make minimum wage per day plus $50 \%$ in benefits, managers make approximately $\$ 5.00$ a day including benefits, $85 \%$ of the workforce is production labor and all workers are employed for 250 days a year.

32 "Over the 1988-92 period, the kernel yield in Mozambique was $18.7 \%$...well below the 23-25\% results obtained in India" (World Bank, 1995b). However, the type of processing technology employed is not the only reason for this difference. According to Deloitte and Touche (1997), "Raw nuts purchased by factories in India are already dried and usually graded by farmers or traders, allowing for higher out-turn or kernel recovery which is said to be $26.5 \%$."

${ }^{33}$ Note in Table 8 that the finding that the value added by the Mozambican processing industry has been marginal or negative is highly dependent on the prices of raw and processed cashews, which are relatively volatile, and on the kernel yield per ton of raw nuts that is assumed. As illustrated in Table 10, which is based on Deloitte and Touche (1997), the value added by the Mozambican industry was positive between 1994/95 and 1996/97.

${ }^{34}$ In 1990, there were 638 processing factories in India, the majority of which were located in the state of Kerela (Nomisma, 1994). However, it is unclear whether home-based processing operations are included in this figure. Nomisma (1994) estimated that in 1990, 280,000 workers were employed in the Indian processing industry and $90 \%$ of them were female.
} 
yields a higher proportion of whole kernels, there are costs in terms of labor standards. Raw cashews contain a corrosive and toxic liquid called cashew nut shell liquid ${ }^{35}$ (CNSL) that can be harmful to workers' hands, causing open sores, if they are not properly protected. The highlymechanized impact and Oltremare processing systems employed in Mozambique prevented workers from coming in direct contact with CNSL. The semi-mechanical system currently employed by Mozambican processing factories is located somewhere between the manual system used in India and the highly mechanized systems previously used in Mozambique on the continuum of workers' exposure to CNSL. The hand and foot-operated semi-mechanical system opens the raw cashew by "clamping two converging blades along a nut's seam and prying it open by cleaving one of the blades" (Abt Associates, 1999).

Others within the World Bank apparently disagreed with the conclusions of the 1995 report. In 1996, the International Finance Corporation (IFC), the World Bank's private-sector financing arm, poured three million dollars into the highly mechanized factory purchased by Anglo-American and Oltremare (IFC, 1996). The negative evaluation of the mechanized factories was also not shared by the private entrepreneurs who purchased and reopened all of these factories during the 1995/96 season. Some observers have suggested that the majority of individuals who purchased the factories simply made poor business decisions and did not accurately calculate the risks, costs, and benefits (of the cashew processing industry). However, an IFC official, Ewen Cobban, asserts that Anglo-American, like many corporations and individuals who purchased the factories, had previous experience operating in the Mozambican cashew industry and therefore "poor business decisions" were not the likely causes of the processing industry's failure (Cobban, 2001). A more recent examination by Abt Associates (1999) has also found that processing technology was not the key problem facing the processing industry:

the problems that confront the cashew processing industry have very little to do with processing per se....(The factories) operate with reasonable efficiency....The real problems that confront and constrain the rehabilitation and development of the cashew processing industry in Mozambique are poor procurement practices and the lack of more aggressive marketing. (Abt Associates 1999)

The issue of appropriate technology hinges in part on the supply of raw nuts. As discussed earlier, there is no longer a constant supply of high quality raw cashews sufficient to meet the processing industry's capacity. This has been particularly problematic for the largescale factories that employ impact and Oltremare technology. In the case of impact technology, the raw nuts must be of a consistent size in order to minimize breakage and produce high quality kernels. The Oltremare processing system produces higher quality kernels, but its high capital cost necessitates large volumes of raw nut throughput (Deloitte and Touche, 1997). Conversely, the semi-mechanical technology employed by the factories that remain operational can effectively process nuts of varying size and it produces a higher quality kernels at a lower cost. When the factories were privatized, there was an implicit assumption that the constant supply of quality nuts that had existed in the past would continue (Abt Associates, 1999). ${ }^{36}$

\footnotetext{
${ }^{35}$ Historically, CNSL was a valuable product of the raw cashew nut until synthetic substitutes were developed.

${ }^{36}$ However, World Bank official Johannes Zutt asserts that the supply of raw nuts may not be as limited as the processors imply, for the processors are "extremely opportunistic" (Zutt, 2001). Several large processing factories are owned by trading companies. Such companies choose to process raw nuts when it is profitable and otherwise
} 
Finally, labor costs have been cited as a significant expense for the factories that were privatized in 1995 and a factor in their inability to continue operating. Many owners of these factories were forced to pay arrears for past labor when they purchased the factories. In addition, under Mozambican law they were obligated to compensate workers for periods in which the factories were not operational if the workers had not been formally given advance notice of a plant closure and laid off. It is estimated that the total amount of severance and other payments factories owe workers is approximately $\$ 5$ million (Abt Associates, 1999).

Whatever the reasons for the failure of the industry, it is clear that without an increase in the supply of raw nuts, there will be no vibrant processing industry in Mozambique. The capacity of the smaller firms pales in comparison to Mozambique's potential. And although the reasons remain unclear, even these small firms appear to be having trouble turning a profit.

\section{Dynamic Effects: Why Hasn't There Been a More Vigorous Supply Response?}

What does it take to get farmers to plant new cashew trees and market more raw cashew? ${ }^{37}$ Output response to increases in producer prices in Mozambique has been disappointing, and this is also true in much of the rest of Sub-Saharan Africa (UNCTAD, 1998). In general, price and non-price incentives are both important in driving farmers' decisions to plant new cashew, and structural constraints can often be the determining constraint (Heltberg and Tarp, 2001). We focus here on the credibility of policy reforms and farmers' expectations regarding future policies.

Credibility of reforms is important because farmers in Africa have often gotten the short end of the stick. Prior to independence, farmers were at the mercy of colonialists who often got their way by physical means (Isaacman, 1996). Independence did not make things a whole lot better for the farmers. For example, Mole (2000) suggests that the collapse of the rural marketing system in Mozambique during the fight for independence and later civil war had a devastating effect on farmers' expectations. They lost confidence in the marketing system as a source of goods for which cashew income could be exchanged. In addition, the organizational structure of the post-independence cashew sector excluded traditional authorities from discussions about the development of the cashew sector. The result was that efforts at promoting cashew tree planting did not succeed because farmers were suspicious and fearful that the government would later nationalize the trees.

Of course none of this would matter if the returns to investing in cashew occurred instantaneously, so that current prices were all that farmers needed to know to make decisions. But in fact there are large time lags, and investment in cashew entails significant sunk costs. Under current conditions, the most important input to cashew production is labor. Approximately $50 \%$ of labor's time is spent harvesting cashew during the period from September to January. The remaining $50 \%$ of labor's time is spent caring for the cashew trees prior to harvest (based on

they export the raw nuts. Therefore, the failure of the processing industry may simply demonstrate the relative benefit of exporting the nuts and the costs of processing (Zutt, 2001).

${ }^{37}$ The majority of Mozambique's cashew orchard was planted in the 1960s. Since these trees have a maximum productive life of 40 years (and typically are considered unproductive after 25 years), the future of the cashew industry in Mozambique depends critically on new planting. 
Mole, Table A-1.2, 2000). Thus, 50\% of the farmer's cost associated with cashew production from existing trees is a sunk cost, incurred before the harvest price is known. Once the farmer has spent time tending the trees - the only way he can hope to recover some of those costs is by harvesting the cashew even if the price he receives for the raw cashew doesn't cover the costs of maintaining the trees. Investing in new trees -- even using existing trees as planting material -entails even greater sunk costs. Trees typically take from 3-5 years to bear any fruit at all and take longer to bear enough fruit to make the investment worthwhile. The labor involved in tending to these trees as well as the opportunity costs associated with planting new cashew trees (not planting food crops) are all sunk costs.

The sunk costs associated with planting new cashew trees make a credible pricing policy both more important and more difficult to achieve. From the farmers' point of view promises by the government to cover the farmers' sunk costs are not credible in the absence of a commitment mechanism. This is because opportunistic governments have an incentive to cheat farmers out of these sunk costs by paying them the minimum required for them to bring their crops to market that is, to pay them only their harvesting costs. Anticipating this eventuality, farmers will of course have no incentive to plant in the first place. Therefore, if the government is unable to precommit to an adequate price, the static, one-shot equilibrium in this game is one in which farmers withdraw from production and the government gets no revenue.

Repeated interaction between farmers and the government make a cooperative outcome more likely but not inevitable. As discussed in McMillan (2001) and McMillan and Masters (forthcoming), in order for a cooperative outcome to be sustained, the farmer's share of sunk costs in total costs must be relatively small (yielding a low potential payoff to exploitation by a rent-seeking government), the government's discount rate must be relatively low, and the revenue the government expects to earn from the crop in the future must be relatively high (leading to a high value on the future costs of exploitation in the present). Surely the uncertainty about the future generated by the long civil war was enough to ensure that Mozambique's cashew sector would end up in a high-tax equilibrium.

One objection to this description of the situation in Mozambique might be the fact that private traders (and not the government) have been purchasing cashew from farmers for over ten years. However, privatization of the marketing sector is not enough to overcome the timeconsistency problem. Since competition among traders at the village level is minimal, opportunistic traders have the same incentives as opportunistic governments to cheat farmers out of sunk costs. Arguably, the traders face even more uncertainty about the future than the government and hence will discount even more heavily future revenue relative to current revenue. Thus, the privatization of the marketing system does not make this problem go way and possibly makes it worse.

The situation is further complicated by the fact that the government is not undertaking the reforms completely of its own volition. Reforms in the cashew sector have been - and still are - a pre-condition for obtaining World Bank money. As Rodrik (1989) points out, this exacerbates the time-consistency problem. Even if the government is not serious about reforms in the cashew sector, it has an incentive to embark on the reform in order to gain access to foreign assistance. But this increases the likelihood that an observed reform will later be reversed. Thus, the 
question that remains is not just how to move from the bad state to the good state, but how to get farmers to believe that the good state will last.

The supply response depends, at a minimum, on communicating the reform and its objectives to farmers. Even if the government fully intends to make good on its promises, this is of little use if the farmers are actually unaware of the regime shift in pricing. In the cashew case, it is astonishing how little communication there has been with farmers about the reforms in the cashew sector. Not only were farmers not involved in designing the reform package, for the most part they were unaware that substantial reforms were taking place. According to former World Bank Country Director Phyllis Pomerantz, the government never officially announced the outcome of its negotiations with the World Bank over the export tax. Given the critical importance of the supply response, this has been a particularly important oversight. Communication with farmers could also help overcome the time-consistency problem, if only by increasing the costs of any later policy reversal. Increasing farmers' awareness can also strengthen their bargaining power vis-à-vis traders making it more difficult for traders to pay low prices. By joining together to form a cohesive bargaining unit, they may even be able to put pressure on traders to raise farmgate prices.

Communicated policy must also be credible to be effective. Enhancing credibility might take several forms. Institutions that increase the farmers' bargaining power -- such as unions -could help increase credibility on several fronts. The option of cheating farmers out of sunk costs becomes less attractive to traders when farmers have more effective means of retaliation for low farmgate prices. Organizing farmers would also help increase their understanding of what to expect and what to do when they don't get what they were expecting. Irreversible investments and/or large up-front expenditures in the cashew sector by the government could enhance credibility by making it costly for the government to allow things to go bad in the cashew sector. Finally, changes that enable producers to escape taxation or retaliate against it, while not directly affecting the credibility of reforms, diminish the importance of credibility by minimizing the cost to farmers of a deceitful government.

What kinds of irreversible investments might the government undertake? Some of the non-price mechanisms highlighted by Mole (2000) and Heltberg and Tarp (2001) could be a place to start. For example, bad roads and a lack of transportation help to keep the marketing sector uncompetitive. By investing in these things, the government can help to make marketing more competitive and cashew farming more profitable. Access to credit is an important deterrent to competition in the marketing sector. Providing traders with access to trade credit at reasonable rates is an important initiative that could make cashew marketing more competitive. To the extent that these initiatives send a signal to traders that the government is serious about making reforms in the cashew sector work, they could have the effect of lowering the traders' discount factors and making a cooperative outcome more likely. Credit is also a problem for farmers. The more sophisticated technologies for cashew growing require substantial outlays of cash in the early stages of development. Providing farmers with access to credit to undertake these new improved techniques sends a signal to farmers that the government is serious about revitalizing the cashew sector. 
Technological improvements that lower sunk costs by reducing the long waiting period between initial planting and fruition, could help to minimize the time-consistency problem by reducing the incentive to cheat farmers out of sunk costs. Mole (2000) provides an example in the context of increasing the overall productivity of the cashew orchard: top-working. Topworking consists of using the rooting system of an old tree to graft on improved planting material. This has the effect of pushing the initial production period up; with superior material, production can begin within 18 months (compared with 3-5 years). This type of technological advance substantially lowers the farmers' sunk costs making predatory taxation less likely. The obvious question is who is going to invest in this type of $\mathrm{R} \& \mathrm{D}$, for that too involves sunk costs. Government investment in this type of R\&D might be one way to signal to farmers that the government is serious about revitalizing the cashew sector.

\section{Concluding Remarks}

In January 2001, suspecting that the exporters were under-invoicing their shipments in order to avoid paying the export tax, the Mozambican government placed a temporary embargo on the export of raw cashew nuts to India (AIM, February 7, 2001). It appears that the embargo was lifted quickly when the government subsequently determined that the prices reflected the decline in the world market price (Zutt, 2001). Nonetheless, the episode demonstrates the shaky nature of the reform and the fragility of the pricing regime that governs cashew exports. After more than ten years of attempted reform, there is little to show for it.

Our analysis indicates that there were several reasons for this failure. On the economic side, the reforms took little note of important market imperfections such as the multi-layered marketing chain and the monopsony role of India that reduced the benefits to cashew farmers. There was virtually no attention paid to the credibility of policy changes and how to enhance it. The government made little effort to manage the political fallout that should have been quite predictable ex ante. And the World Bank did not sufficiently appreciate the ineffectiveness of buying reform through aid-cum-conditionality. In all these respects, Mozambican cashews provide an illuminating case study of the misfortunes that have befallen the reforms that African countries undertook in the last couple of decades. 


\section{Appendix A: The Debate}

The opposition to the World Bank's policies in the cashew industry is multi-faceted. Many opponents assert that decreasing the export tax would not have led to increases in producer prices and cashew production as predicted by the World Bank (see Hanlon 2000). Hanlon and others (including Carlos Cardoso, a journalist who was subsequently murdered) claim that the peasant farmers did not gain from the liberalization of exports. They point to traders as the main beneficiaries (Hanlon, 2000, Whewell, 2000). Fauvet (2001) asserts that the policy actually harmed the producers, who had benefited from competition for raw nuts. He cites that the producer price fell by $50 \%$ when the factories closed. ${ }^{38}$

Critics of the World Bank claim that owners who purchased the processing factories from the government in 1995 required a period of protection in order to rehabilitate the factories following the civil war and the period of government operation in which the equipment had deteriorated. According to Hanlon (2000), "there was an informal agreement with the owners of the newly privatized companies that they would be given a period of protection while they rehabilitated and modernized the factories." According to Fauvet, the agreement to continue protecting the processing industry was even more explicit:

AICAJU, the cashew processors association, argues that the government defaulted on the contracts signed with the new owners. The contract with Angocaju, for instance, clearly stated the government would guarantee the supply of raw nuts to the factories, and only nuts surplus to the factories' requirements would be exported. (Fauvet, 2001)

Without a ban on exporting raw nuts or a prohibitively high tax, the processing factories could not obtain enough raw cashew nuts to operate. According to Mondlane, the policy has "effectively stimulated the export of raw nuts to India, starving the local processing industry of its raw material" (Panafrican News Agency, 1999). Derek Higgo, managing director of Mocita, claims that the inadequate supply of raw nuts was a key problem (Whewell,2001).

Opponents also cite the financial costs of liberalizing the cashew industry:

For every ton of raw nuts exported, Mozambique loses $\$ 150$ that it would have earned had that same ton been converted into processed kernels. The Frelimo deputies estimate this loss over the past four years at \$12 million. Businesses invested \$25 million in cashew processing after 1994 - this risks being a total write-off. (AIM, 1999).

These opponents assert that Mozambique cannot compete with Indian cashew processors without protection. They argue that protection is warranted given Indian labor standards and Indian trade policies that we discussed in the paper.

The critics argue that the World Bank did not consider the risk that Mozambican producers would become dependent on India as a single buyer. Indian merchants are currently paying the same prices the factories were willing and able to pay. According to Cobban (2001), the World Bank's policy effectively destroyed not only the Mozambican processing industry, but also any competition that the Indian buyers faced. In addition, India has a policy of expanding domestic cashew production in order to meet its processing capacity. Critics question who will

\footnotetext{
${ }^{38}$ The farm gate price fell by $50 \%$ in 2001 , however the FOB price also decreased by $43 \%$ (Desai, 2001a).
} 
buy Mozambican raw nuts if the Mozambican processing factories close and the Indian demand for imported raw cashews decreases (Torcato, 1998).

Owners and operators of the large-scale, capital-intensive processing factories that have closed assert that they cannot and should not be forced to compete against an Indian industry with lower labor standards. As discussed earlier, India's cashew industry depends more on manual labor to shell raw nuts. According to Jeter (2000), this system is cheaper, but exposes workers to the toxic CNSL. According to Derek Higgo, workers at the Mocita processing factory, which employed automated processing technology, did not come into direct contact with CNSL, but that is not the case in the Indian industry (Whewell, 2000).

Finally, opponents criticize the World Bank for infringing on Mozambique's sovereignty and forcing it to accept policies against its will (Hanlon, 2000). According to Mozambican President Joaquim Chissano, Mozambique "had to liberalize the export of raw cashews in order to obtain other benefits from the Bretton Woods institutions." Specifically, he asserts that Mozambique complied with the World Bank's liberalization policy in order to qualify for HIPC debt relief. However, he asserts that the cashew industry was sacrificed as a result (AIM, June $25,2001)$.

While the opposition has succeeded in drawing a great deal of attention to the World Bank's intervention in the Mozambican cashew industry, it has also been the subject of criticism itself. In a New York Times editorial, Paul Krugman (2000) criticized the opposition, particularly Robert Naiman of the Center for Economic and Policy Research, for not fully understanding the case. He asserted that the rural peasant farmers, who lack political power, were forced to bear the cost of the export tax which forced them to sell their crop cheaply to the domestic processing industry. The export tax, according to Krugman, was a means of protecting the processing industry and its relatively small number of politically influential factory owners and workers. He concluded that the export tax had a net negative impact on Mozambique and that World Bank was justified in making loans conditional upon reducing the export tax.

Naiman responded to Krugman's editorial in a New York Times letter to the editor. The New York Times, however, published an abbreviated version of Naiman's original letter. In the unabridged letter, Naiman asserts that the Bretton Woods institutions exercise "colonial power over developing countries" and that the "dogmatic trade liberalization" that they impose hurts developing countries (Naiman, 2000a). Naiman also provides some figures to counter Krugman's claim that the World Bank policy has benefited the poor. In the published version, Naiman cites the Deloitte and Touche Report (1997) which, Naiman asserts, found that "Mozambique's peasants did not gain anything from liberalized exports of raw cashews" (Naiman, 2000b). ${ }^{39}$

\footnotetext{
${ }^{39}$ We have been unable to find this quotation in Deloitte and Touche (1997). The report does state that, "These concessions to liberalization (reducing the export tax), with the assistance of the gradually increased minimum farmer price, and the diminishing supply of raw nuts, have sharpened the competitive trade in the rural areas resulting in a trend of increasing producer price, especially toward the end of the 1997 buying campaign. However, it is only those large farmers with the ability and financial capacity to store nuts that have benefited."
} 
Graham Mann (2001) has echoed Pual Krugman's arguments. He criticizes Paul Fauvet, an opponent of the World Bank, for not fully understanding the case. He asserts that reducing the tax on raw cashew exports, as advocated by the World Bank, led to increases in farm-gate prices between 1996 and 1999. He further asserts that the producer benefits would have continued had the Government fully implemented the World Bank policy and completely eliminated the export tax. Mann counters the opposition's claims that the factories failed because of an inadequate supply of high quality raw cashew nuts. He states that "more than half of these factory owners who complain about having no nuts for their factories were also exporting raw cashew nuts in all sorts of discounted arrangements with India." Mann implies that factories that did fail due to inadequate supplies of raw nuts made poor business decisions. He states that Mocita was advised that it would only be viable if it could run at full capacity, yet it proceeded to rehabilitate the factory despite the fact that the supply of high quality nuts at the time was insufficient.

\section{Recent Developments}

In 1999, a bill entitled "Proposed Bill for the Cashew Sub-Sector Reindustrialization in Mozambique" was introduced in the Parliament. "The bill proposed to ban the export of raw cashew nuts, that priority be given to first supplying the local processing industry, and that market prices be set at the producer level" (Mole and Weber, 1999). However, this bill was not passed in its original form. "In October, 1999, the National Assembly passed a law providing for an increase in the export tax on raw cashew nuts from $14 \%$ to $18-22 \%$ and for a first right to purchase raw nuts for the benefit of indigenous processors" (IMF, 2001).

A national meeting on the cashew industry was held in Nampula on July 5, 2001. This meeting focused primarily on ways to increase cashew production. According to Agriculture Minister Helder Muteia, the government has introduced a program to expand and renew the cashew orchard, increasing production to more than 100,000 tonnes within three years (AIM, July 5, 2001). This is to be accomplished through improving planning and cashew farming techniques, including chemically treating trees. The meeting also addressed issues of concern to the processing industry. It recommended liquidating several inefficient processing factories that are not currently operating, including Mocaju, Procaju Inhambane and Manjacaze, and Polycaju. It also recommended terminating redundant workers' employment and changing the labor laws to facilitate hiring temporary labor. 


\section{References}

Abt Associates, Inc. (1999). "Assessment of the Status of Competitiveness and Employment in the Cashew Processing Industry in Mozambique.” Abt Associates, Bethesda, Maryland

AIM (Mozambique New Agency) (February 8, 1999). Report. No. 151

AIM (Mozambique New Agency) (February 7, 2001). Report. No. 200

AIM (Mozambique New Agency) (April 3, 2001). Report. No. 204

AIM (Mozambique New Agency) (May 15, 2001). Report. No. 207

AIM (Mozambique New Agency) (June 25, 2001)

AIM (Mozambique New Agency) (July 5, 2001)

Arulpragasam Jehan. (2001). Personal interview, July 2, 2001

Cobban, Ewen. (2001). Phone interview, July 25, 2001

Cramer, Christopher (1999). "Can Africa Industrialize by Processing Primary Commodities? The Case of Mozambican Cashew Nuts," World Development, Vol. 24, No. 7, pp. 1247-1266

Deloitte and Touche ILA (Africa) and Deloitte Touch Tohmatsu Sisteconta. (1997). Cashew Marketing Liberalization Impact Study. Government of Mozambique, Maputo

Desai, Jaikishan (2001a). "Cashew Production and Marketing in the Smallholder Sector in Mozambique."40 Unpublished report for the World Bank

Desai, Jaikishan (2001b). Personal interview, July 2, 2001

Desai, Jaikishan (2001c). E-mail dated August 2, 2001. Based on his conversation with an unnamed Indian cashew broker.

EIU (2000), Mozambique Country Memo. March

FAO (2000). FAOSTAT Agriculture Data

Fauvet, Paul. (2001). "World Bank Crushes Mozambique's Cashew Industry." Business Report. May 23, 2001. South Africa

Feenstra, Robert (2000). World Trade Flows, 1980-1997. Institute of Governmental Affairs, University of California, Davis. Davis, CA

\footnotetext{
${ }^{40}$ The World Bank did not classify this report as "Grey Cover.” I will ask Peter Moll how it should be cited.
} 
Hanlon Joseph (2000). "Power Without Responsibility: the World Bank and Mozambican Cashew Nuts." Review of African Political Economy. Volume 83, March 2000

Heltberg, Rasmus and Finn Tarp (2002). “Agricultural Supply Response and Poverty in Mozambique,” Food Policy, 27 (2002) 103-124

Hilmarsson, Hilmar T. (1995). Cashew Pricing and Marketing in Mozambique. World Bank Working Paper prepared for a seminar in June 1995, Maputo

International Monetary Fund (IMF). (2001). "Mozambique: 2000 Article IV Consultation and Second Review Under the Poverty Reduction and Growth Facility - Staff Report; Staff Statement; Public Information Notice and Press Release on the Executive Board Discuss; and Statement by the Authorities of Mozambique." January 17, 2001

INCAJU (Instituto de Fomento do Caju). (2001). Data obtained from Ana Machalela through e-mail dated July 20, 2001

INCAJU (Instituto de Fomento do Caju). (2001b). Data obtained from R. Matule through email dated September 27, 2001

INCAJU (Instituto de Fomento do Caju). (1998). "Cashew Master Plan: Production Component." Maputo, Mozambique

Isaacman, Allen. (1996) Cotton is the Mother of Poverty: Peasants, Work and Rural Struggle in Colonial Mozambique, 1938-1961 (Portsmouth: Heinemann,1996)

Jaffee, Steven and Morton, J. (1995). Marketing Africa's High-Value Foods: Comparative Experiences of an Emergent Private Sector. Kendall/Hunt, Dubuque

Jeter, Jon. (2000). "In Mozambique, a Less Than Helpful Hand: World Bank, IMF Blamed for Fall of Mozambican Cashew Industry." The Washington Post. October 18, 2000

Kottak, Nicholas. (2001). Phone interview, July 14, 2001

Krugman, Paul. (2000) “Reckonings; A Real Nut Case.” The New York Times. April 19, 2000

Mangwiro, Charles. (1999). "Mozambique Cashew Industry Close to Collapse” Daily Mail and Guardian. Johannesburg, South Africa, January 29, 1999

Matule, Raimundo, Deputy Director INCAJU. (2001). Personal interview, October, 2001

McMillan, Margaret (2001) "Why Kill the Golden Goose? A Political-Economy Model of Export Taxation," The Review of Economics and Statistics, vol. 83, issue 1, pp 170-184 
McMillan, Margaret and Masters, William (2001) "An African Growth Trap: Production Technology and the Time-Consistency of Agricultural Taxation, R\&D and Investment," Review of Development Economics (forthcoming)

Mole, Paulo Nicua (2000). “An Economic Analysis of Smallholder Cashew Development Opportunities and Linkages to Food Security in Mozambique's Northern Province of Nampula." Ph.D. diss., Michigan State University

Mole, Paulo and Michael Weber (1999). “The Cashew Debate in Mozambique: Are There Alternative Strategies?" Flash...Research Findings from the Food Security Project in Mozambique. No. 16E

Moll, Peter. (2001). Phone interview, August 1, 2001

Mooney, Timothy. (2001a). Phone interview, June 21, 2001

Mooney, Timothy. (2001b). Personal interview, July 3, 2001

Mosca, João and Delgado, Felisa Ceña. (1994). "Ajustamento Estructural e Segurança Alimentar: O Caso de Moçambique,” Extra, Maio/Agosto 1994, Centro de Formação Agrária e de Desenvolvimento Rural, Maputo

Naiman, Robert. (2000a). Unpublished version of New York Times letter to the editor. April 20, 2000. http://www.fair.org/articles/naiman-krugman.html

Naiman, Robert. (2000b). "World Bank’s Power." The New York Times. April 26, 2000

Newitt, M. (1995). A History of Mozambique. Hurst, London in Cramer, 1999

Nicholson, Patrick (2001) "Mozambique:The effects of trade liberalization," unpublished report for CAFod

Nomisma (1994). The World Cashew Economy. Edizioni L'inchiostroblu. Oltremare SpA.. Bologna, Italy

Nomisma (1987). The World Cashew Economy. Edizioni L'inchiostroblu. Oltremare SpA. Bologna, Italy

Owen, Dan. (2001). Personal interview, July 3, 2001

Panafrican News Agency (PANA). (1999). Daily Newswire, December 29,1999

Penvenne, Jeanne. (1997) "Seeking the Factory for Women: Mozambican Urbanization in the Late Colonial Era," Journal of Urban History, Vol. 23, No. 3 (March, 1997): 342-379

Pomerantz, Phyllis. (2001a). Personal interview, July 3, 2001 
Pomerantz, Phyllis. (2001b). E-mail dated September 25, 2001

Prasad, M. and Americo Uaciquete (1997). "Genetic Upgrading of Cashew in Mozambique." Proceedings of the International Cashew and Coconut Conference, $17^{\text {th }}$ to $21^{\text {st }}$ of February, Dar Es Salaam, Tanzania

Rodrik, Dani. (1989) "Promises, Promises: Credible Policy Reform via Signaling," The Economic Journal, 99, September, 1989

Sampat, Harish. (2001). Information obtained from Harish Sampat, Samsons Trading Company, Bombay in an e-mail dated October 13, 2001

Sowa, Arnold. (2001). Phone interview, July 24, 2001

Tarp Finn. (1990). "Prices in Mozambican Agriculture.” Journal of International Development, Vol. 2, No. 2, 172-208

Tirole, Jean. (1988). The Theory of Industrial Organization. Cambridge, MA, MIT Press

Torcato, Maria de Lourdes. (1998). “Caju - há luz no fundo do túnel?” MoçAmbiente, MarçoAbril 1998, Maputo in Hanlon, 2000

UNCTAD. (1998). Trade and Development Report, United Nations, New York and Geneva, 1998

UNCTAD. (2001). Trade Analysis and Information System (TRAINS).

www.unctad.org/trains/index.htm

UNDP. (1998) National Human Development Report for Mozambique, UNDP, Maputo, 1998

Vegarra, German. (2001). Phone interview, July 18, 2001

Whewell, Tim. (2000). "Mozambique: Going Nuts About the World Bank." BBC News, August 18, 2000

World Bank (2002). (Email communication with Daniel Souza) April 5, 2002

World Bank (2000a). "Briefing Note on Cashew Policy" World Bank, Washington, D.C.

World Bank (2000b). Country Assistance Strategy. Report no. 20521-MOZ. World Bank, Washington, D.C.

World Bank (1997). Country Assistance Strategy. Report no. 17180-MOZ. World Bank, Washington, D.C. 
World Bank (1995a). Country Assistance Strategy. Report no. 15067-MOZ. World Bank, Washington, D.C.

World Bank (1995b). Mozambique: Impediments to Industrial Sector Recovery. Report no. 13752-MOZ. World Bank, Washington, D.C.

Xinhua News Agency (1999). "Mozambican Cashew Workers Call for Protection." September 3, 1999

Zutt, Johannes. (2001) Phone interview, September 20, 2001 


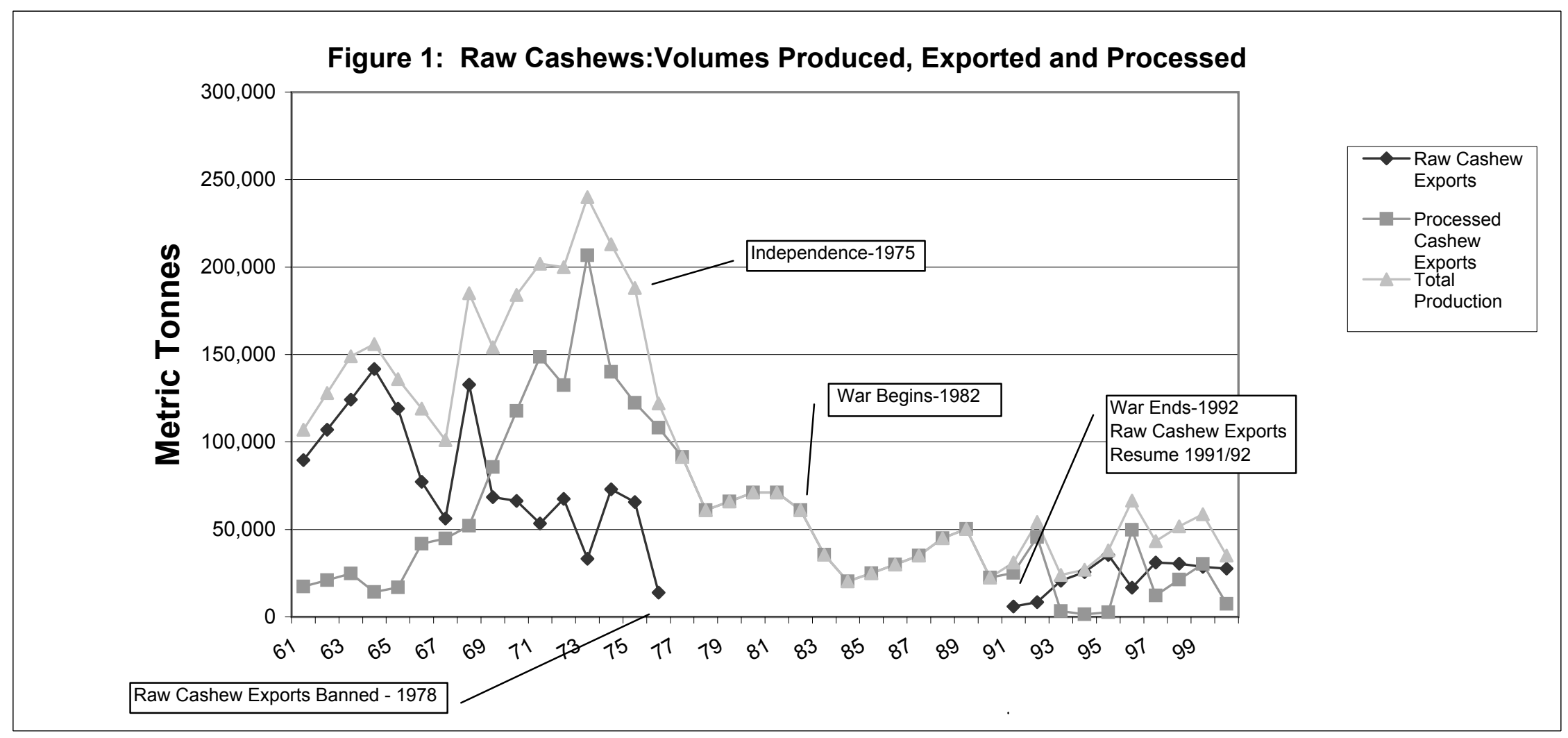


Table 1

Hypothetical Supply Response for Raw Nuts

Source: World Bank (1995b)

\begin{tabular}{|c|c|c|c|}
\hline & Thousand Tons & Export Value (Million US\$) & Farmers' Income (Million US\$) \\
\hline \multicolumn{4}{|c|}{ Producer Price US\$ $0.375 \mathrm{~kg}$ - Producer Share $50 \%$} \\
\hline Short-term & 46.6 & 34.9 & 17.4 \\
\hline Medium-term & 54.3 & 40.9 & 24.5 \\
\hline Long-term & 96.7 & 72.5 & 36.2 \\
\hline \multicolumn{4}{|c|}{ Producer Price US\$ $0.45 / \mathrm{kg}$ - Producer share $60 \%$} \\
\hline Short-term & 49.9 & 37.4 & 22.4 \\
\hline Medium-term & 59.9 & 44.9 & 29.9 \\
\hline Long-term & 114.7 & 86 & 51.6 \\
\hline \multicolumn{4}{|c|}{ Producer Price US\$ 0.525/kg - Producer share 70\% } \\
\hline Short-term & 53.3 & 39.9 & 27.9 \\
\hline Medium-term & 65.5 & 49.1 & 34.4 \\
\hline Long-term & 132.6 & 99.4 & 69.6 \\
\hline
\end{tabular}

The table assumes an initial production of 35,000 tons of raw cashew nuts

Short term is 1-2 years

Medium term is within 5 years

Long term is within 10-15 years

Elasticities for scenario are: 0.15 (short term), 0.25 (medium term), and 0.80 (long term)

Source: World Bank, $1995 b$ 
Table 2

Schedule of Export Tax (Proposed and Actual)

\begin{tabular}{|l|r|l|l|}
\hline Year & $\begin{array}{l}\text { Industry } \\
\text { Proposal }\end{array}$ & $\begin{array}{l}\text { WB/Industry } \\
\text { Negotiated } \\
\text { Schedule }\end{array}$ & $\begin{array}{l}\text { Actual } \\
\text { Tax }\end{array}$ \\
\hline $1995 / 96$ & $25 \%$ & $20 \%$ & $20 \%$ \\
\hline $1996 / 97$ & $20 \%$ & $12 \%$ & $14 \%$ \\
\hline $1998 / 99$ & $16 \%$ & $7 \%$ & $14 \%$ \\
\hline $1999 / 00$ & $12 \%$ & $5 \%$ & $18 \%$ \\
\hline $\begin{array}{l}2000 / 01 \text { and } \\
\text { continuing }\end{array}$ & $8 \%$ & $0 \%$ & $18 \%$ \\
\hline
\end{tabular}

Source: Deloitte and Touche (1997) and Desai (2001a) 


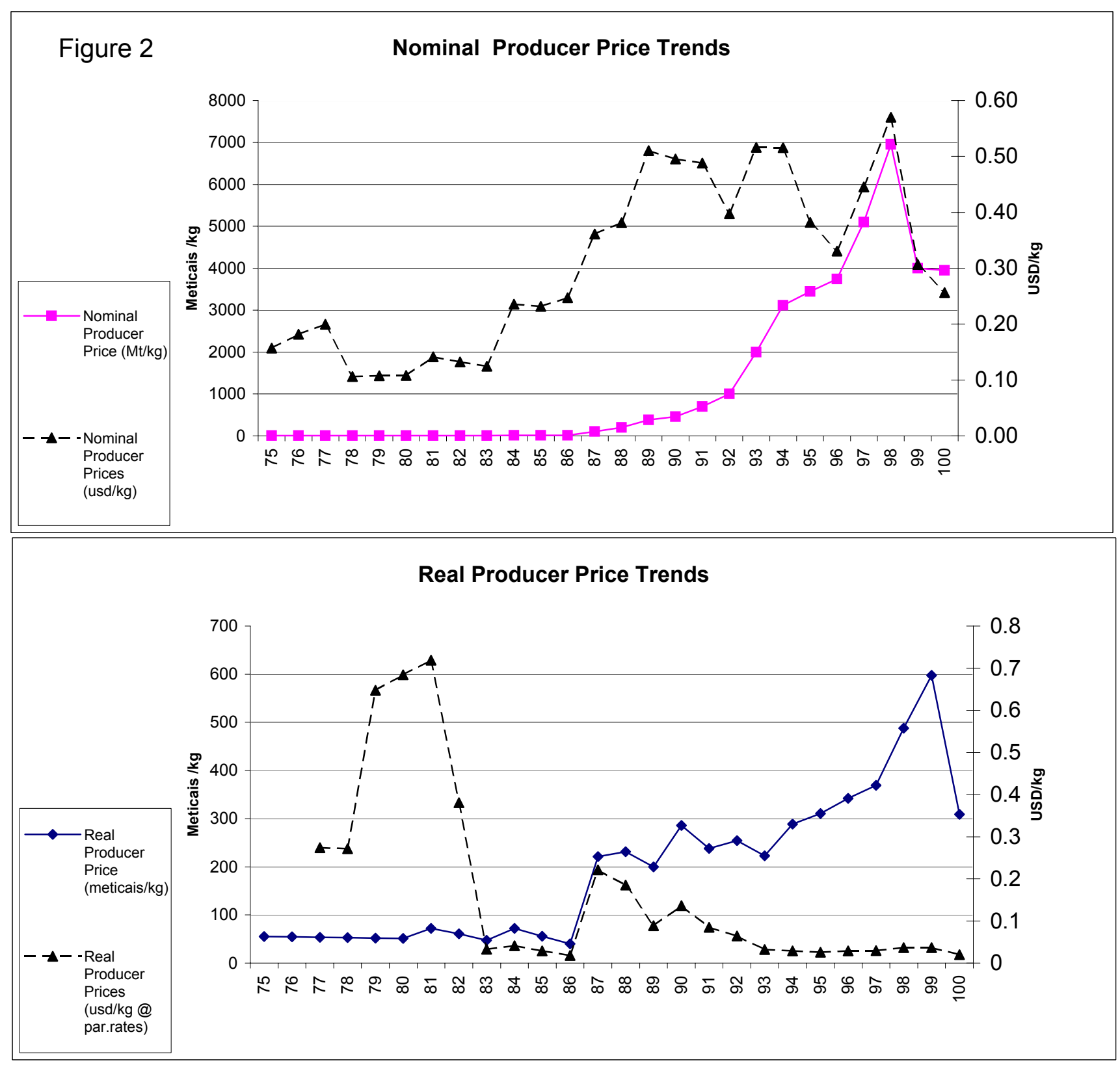




\begin{tabular}{|c|c|c|c|c|c|c|}
\hline Factory Name/(Original Name) & Location & Year Est. & \begin{tabular}{|c|} 
Status: \\
Operational or Yr. \\
Operations Ceased
\end{tabular} & Ownership & $\begin{array}{l}\text { Installed } \\
\text { Capacity } \\
\text { (1) }\end{array}$ & Technology \\
\hline Adil IC & Inhambane & 1995 & 1997 & Mr. Vipino - 100\% & 3000 & impact \\
\hline Africaju & Sofala & & & $(8)$ & & \\
\hline Angocaju/(Angoche) & Nampula & 1971 & 1997 & Gani/Enacomo - 70\%, State - 30\% & 10500 & impact \\
\hline Beira & Sofala & & & $(8)$ & & \\
\hline Cabo Caju & Cabo Delgado & 1995 & $\begin{array}{l}\text { Operates } \\
\text { intermittently (6) }\end{array}$ & Juerg Reiser - 100\% (8) & $2,000(2)$ & semi-mechanical \\
\hline Cajeba & Nampula & 1995 & Officially closed (7) & Grupo JFS - 100\% (Portuguese) (8) & 3500 & semi-mechanical \\
\hline Inducaju-1 & Nampula & 1973 & $1999(2,4)$ & Gani/Grupo AGT- 95\%, State - 5\% & 2500 & oltremare-hand \\
\hline Inducaju-2 & Nampula & 1973 & $1999(2,4)$ & Gani/Grupo AGT- 95\%, State - 5\% & 1250 & semi-mechanical \\
\hline Invape & Gaza & 1998 & Operational $(2,4)$ & V. Mufemane - $100 \%(8)$ & 375 & semi-mechanical \\
\hline Madecaju & Maputo & 1998 & Operational (4) & Alvaro Martins - $100 \%$ & 200 & semi-mechanical \\
\hline Mocaju (Machava) & Maputo & 1965 & $1998(4)$ & Has-Nur - $85 \%$, State - $15 \%$ & 12500 & impact \\
\hline Mocita (in Xai Xai) & Gaza & 1965 & $2001(3)$ & $\begin{array}{l}\text { Anglo-American - } 60 \% \text {, Oltremare, } \\
\text { ED\&FM (8) }\end{array}$ & 8750 & oltremare-auto \\
\hline Monapo & Nampula & 1971 & 1999 & Entreposto - $100 \%(8)$ & 9000 & oltremare-hand \\
\hline Nacala/(Antenes) & Nampula & 1969 & $1999(5)$ & $\begin{array}{l}\text { Entreposto/Grupo AGT- } 43 \% \text {, State- } \\
31 \%(8)\end{array}$ & 9375 & oltremare-hand \\
\hline Polycaju/(Caju Industrial ) & Maputo & 1950 & $1999(2,4)$ & Mr. Cassamo - 95\%, State - 5\% & 3750 & impact \\
\hline Polycaju-Procaju & Maputo & 1950 & $1999(2,4)$ & Mr. Cassamo - 95\%, State - 5\% & 1400 & hammer \\
\hline Procaju-Inhambane/(Inhambane) & Inhambane & 1966 & 1998 & Sara Daude - $90 \%$, State - $10 \%$ & 3750 & impact \\
\hline Procaju-Manjacaze & Gaza & 1965 & 1998 & Sara Daude $-80 \%$, State $-20 \%$ & 3750 & impact \\
\hline Socaju/(Korean-Moz. Cashew) & Inhambane & 1995 & Operational (4) & Antonio Viriato - $100 \%(8)$ & 1250 & manual \\
\hline \multicolumn{7}{|l|}{ Notes } \\
\hline \multicolumn{7}{|c|}{ (1) 1999 - 3 shifts/day -mechanical shelling; 1 shift/day - manual/pedal shelling; operating 250 days/year. } \\
\hline \multicolumn{7}{|c|}{ (2) State Secretariate of Cashew in Mole and Weber, 1999} \\
\hline \multicolumn{7}{|c|}{ (3) AIM, 2001} \\
\hline \multicolumn{7}{|l|}{ (4) Abt Associates, 1999} \\
\hline \multicolumn{7}{|l|}{ (5) INCAJU, $2001 \mathrm{~b}$} \\
\hline \multicolumn{7}{|c|}{ (6) Due to financial problems, operates intermittently, World Bank, Maputo, April, 2002.} \\
\hline \multicolumn{7}{|c|}{ (7) Officially declared closed for "political reasons." Some evidence suggests factory is operating at very low capacity, WB, Maputo, April, 2002.} \\
\hline \multicolumn{7}{|c|}{ (8) Includes foreign ownership, otherwise, exclusively domestic ownership } \\
\hline \multicolumn{7}{|c|}{ (9) Hilmarsson (1995) } \\
\hline \multicolumn{7}{|l|}{ (10) Deloitte and Touche (1997) } \\
\hline
\end{tabular}


Table 3

Summary of Cashew Processing Factories

\begin{tabular}{|c|c|c|c|c|c|c|c|c|c|c|}
\hline Factory Name/(Original Name) & $\begin{array}{c}\text { Reference Price } \\
\text { at Privatisation } \\
\text { (US\$) (9) }\end{array}$ & $\begin{array}{c}\text { Purchase Price } \\
\text { at } \\
\text { Privatisation } \\
\text { (US\$) (9) }\end{array}$ & $\begin{array}{c}\text { Downpaymen } \\
\text { t at time of } \\
\text { purchase } \\
\text { (US\$) (9) }\end{array}$ & $\begin{array}{c}\text { Cost of Equipment } \\
\text { in US\$ }\end{array}$ & \begin{tabular}{|c|} 
Workers \\
Employed, \\
$1995(10)$
\end{tabular} & \begin{tabular}{|c|} 
Workers \\
Employed, \\
$1996(10)$
\end{tabular} & \begin{tabular}{|c|} 
Workers \\
Employed, \\
$1997(10)$
\end{tabular} & \begin{tabular}{|c|} 
Workers \\
Employed, \\
early \\
90s(4)
\end{tabular} & $\begin{array}{c}\text { Processed } \\
\text { in } 1993\end{array}$ & $\begin{array}{c}\text { Processed } \\
\text { in } 1994 \\
(9,11)\end{array}$ \\
\hline Adil IC & & & & $700,000 / 1000$ tons & 140 & 399 & 430 & 500 & & \\
\hline Africaju & & & & 80,000 & 150 & 150 & 150 & & & \\
\hline Angocaju/(Angoche) & $4,210,000$ & $3,000,000$ & 600,000 & $700,000 / 1000$ tons & 419 & 436 & 436 & 975 & 113 & - \\
\hline Beira & $1,140,000$ & 535,000 & 100,000 & $700,000 / 1000$ tons & 217 & 215 & 219 & & & \\
\hline \multicolumn{11}{|l|}{ Cabo Caju } \\
\hline \multicolumn{11}{|l|}{ Cajeba } \\
\hline Inducaju-1 & & & & 80,000 & 446 & 496 & 550 & 548 & 280 & - \\
\hline Inducaju-2 & & & & & 629 & 633 & 786 & & & \\
\hline Invape & & & & 20,000 & & & & & & \\
\hline Madecaju & & & & 20,000 & & & & & & \\
\hline Mocaju (Machava) & $3,230,000$ & & & $700,000 / 1000$ tons & 906 & 906 & 906 & 1,078 & 3,517 & - \\
\hline \multicolumn{11}{|l|}{ Mocita (in Xai Xai) } \\
\hline Monapo & & & & $750,000 / 1000$ tons & 1,290 & 1,344 & 1,406 & 1,088 & 5,655 & 6,000 \\
\hline \multicolumn{11}{|l|}{ Nacala/(Antenes) } \\
\hline Polycaju/(Caju Industrial ) & $1,710,000$ & & & $700,000 / 1000$ tons & - & 1,051 & 1,051 & 765 & 1,091 & - \\
\hline \multicolumn{11}{|l|}{ Polycaju-Procaju } \\
\hline Procaju-Inhambane/(Inhambane) & $1,800,000$ & 900,000 & 90,000 & $700,000 / 1000$ tons & 471 & 555 & 555 & 570 & 1,328 & - \\
\hline Procaju-Manjacaze & $1,200,000$ & 600,000 & 60,000 & $700,000 / 1000$ tons & 563 & 625 & 625 & 326 & 311 & - \\
\hline \multirow[t]{2}{*}{ Socaju/(Korean-Moz. Cashew) } & & & & $700,000 / 1000$ tons & 80 & 80 & 120 & & & \\
\hline & $13,290,000$ & $5,035,000$ & 850,000 & & 6,771 & 8,868 & 10,086 & 8,091 & 13,614 & 6,000 \\
\hline \multicolumn{11}{|c|}{\begin{tabular}{|l|l|l|l|} 
Notes & & \\
\end{tabular}} \\
\hline \multicolumn{11}{|c|}{\begin{tabular}{|l} 
(1) 1999 - 3 shifts/day -mechanical shelling; 1 shift/day - manual/pedal shelling; operating 250 days/year. \\
\end{tabular}} \\
\hline \multicolumn{11}{|c|}{ (2) State Secretariate of Cashew in Mole and Weber, 1999} \\
\hline \multicolumn{11}{|c|}{\begin{tabular}{|l|l|} 
(3) AIM, 2001 & \\
\end{tabular}} \\
\hline \multicolumn{11}{|l|}{ (4) Abt Associates, 1999} \\
\hline \multicolumn{11}{|l|}{ (5) INCAJU, 2001b } \\
\hline \multicolumn{11}{|c|}{\begin{tabular}{|l|l|l} 
(6) Due to financial problems, operates intermittently, World Bank, Maputo, April, 2002. & \\
\end{tabular}} \\
\hline \multicolumn{11}{|c|}{\begin{tabular}{|l} 
(7) Officially declared closed for "political reasons." Some evidence suggests factory is operating at very low capacity, WB, Maputo, April, 2002. \\
\end{tabular}} \\
\hline \multicolumn{11}{|c|}{ (8) Includes foreign ownership, otherwise, exclusively domestic ownership } \\
\hline (9) Hilmarsson (1994) & & & & & & & & & & \\
\hline (10) Deloitte and Touche (1997) & & & & & & & & & & \\
\hline (11) According to Hilmarsson (1994), only o & factory was operationa & in 1994 (p. 18) & & & & & & & & \\
\hline
\end{tabular}




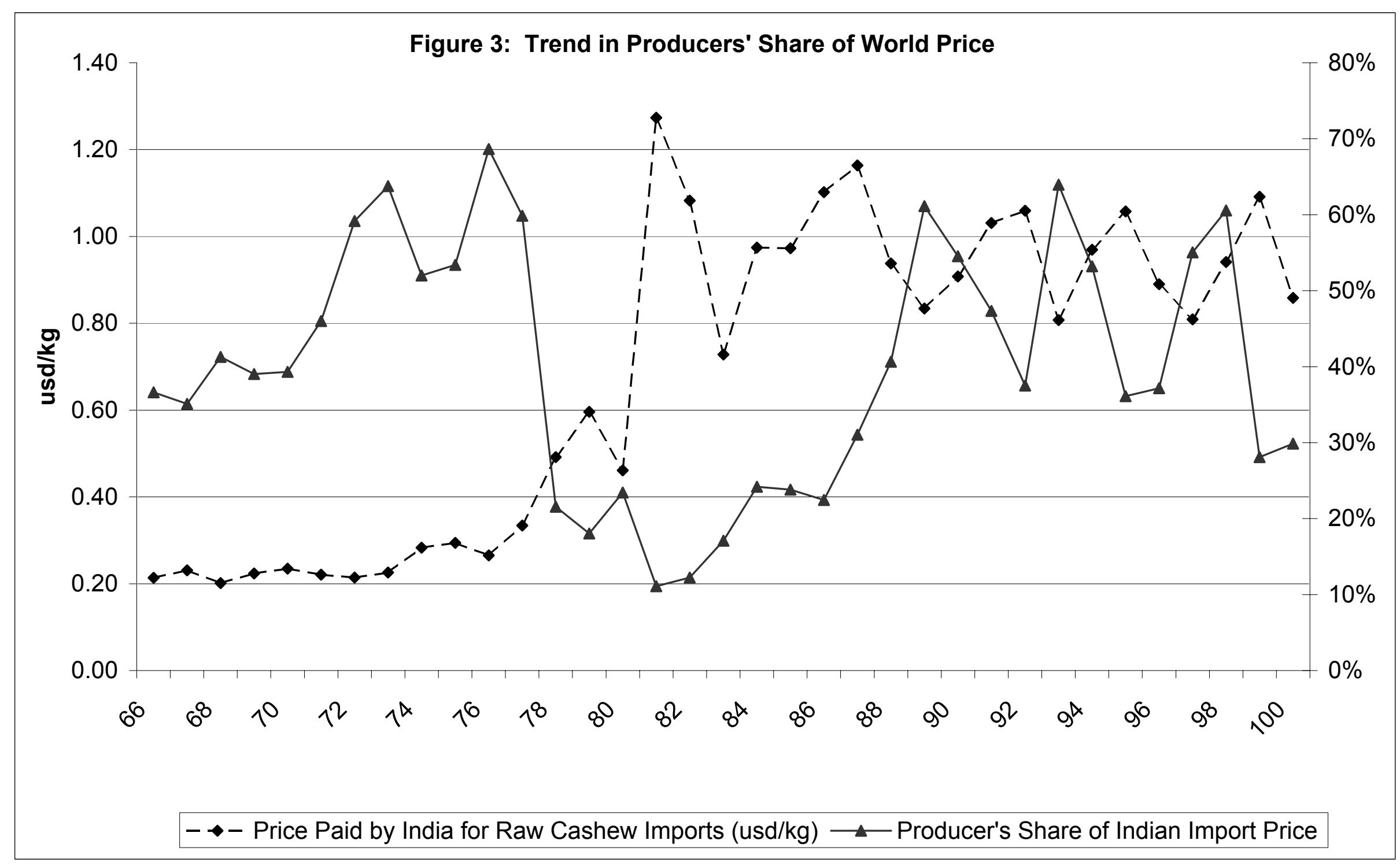




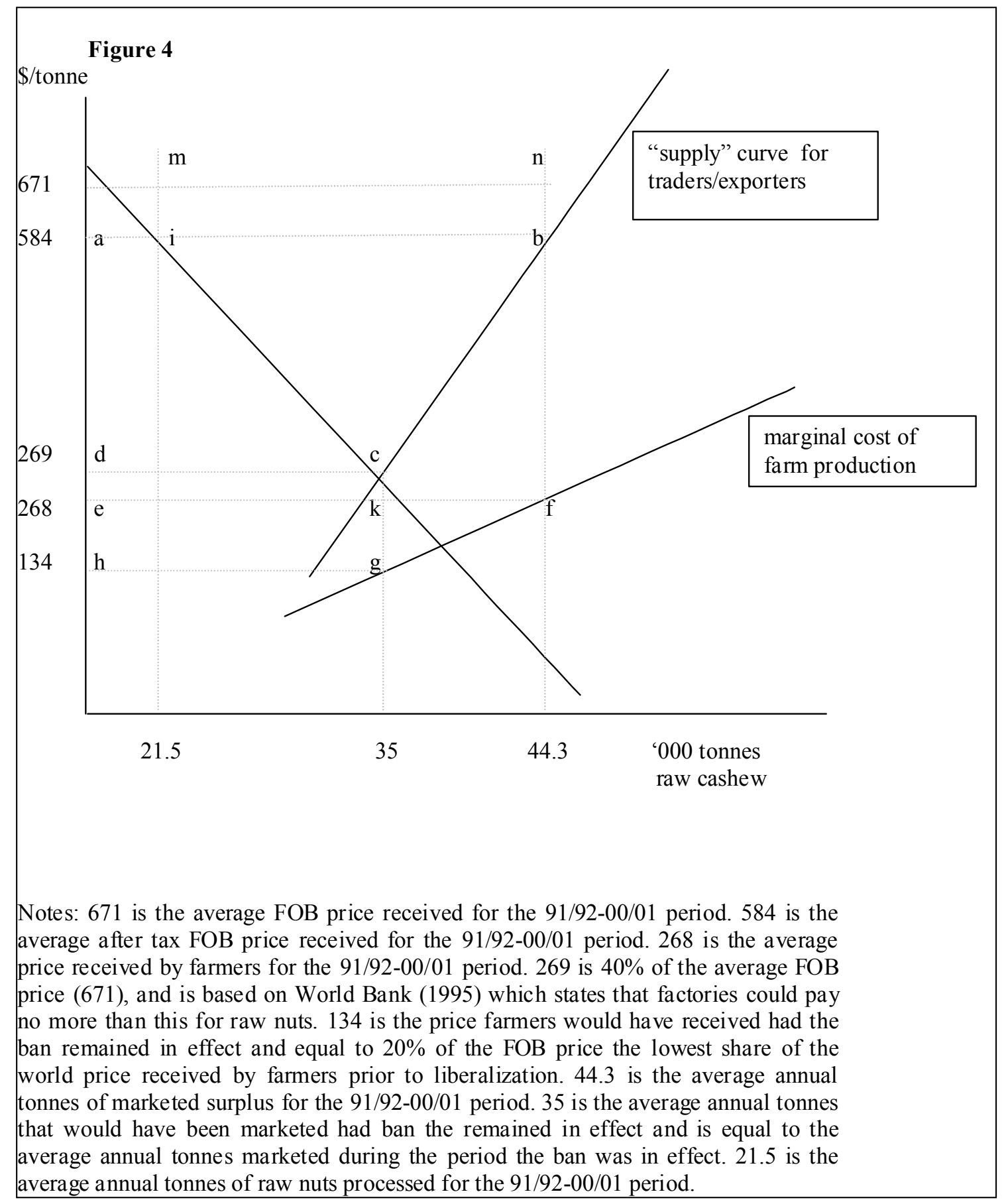


Figure 5: Canais de Distribuição

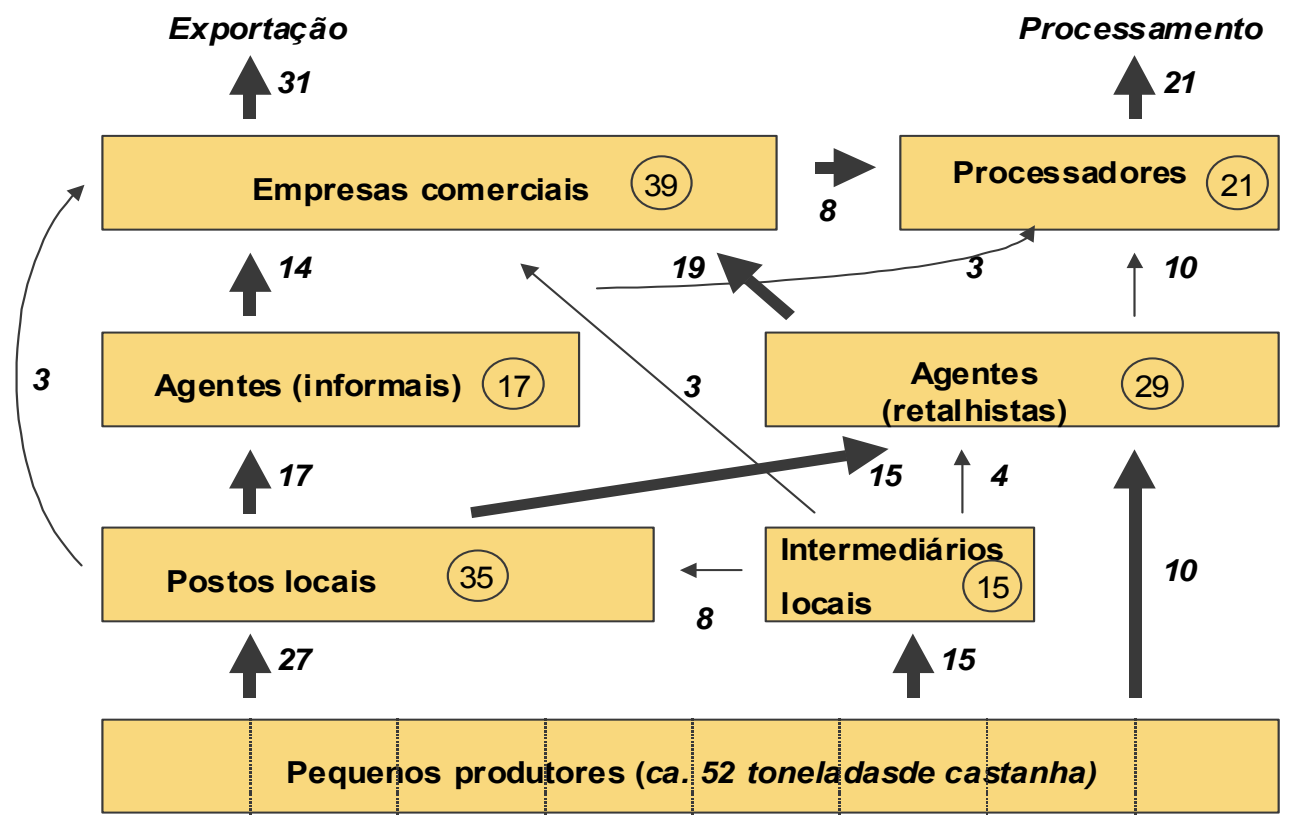

Fonte: Dados compilados a partir de números obtidos junto do Grpo de Trabalho do cajú 


\section{Table 4}

History of Trade Margins and Pricing Structure

$$
1988 / 89 \quad 1989 / 90
$$

$1990 / 91$

$1991 / 92$

$1992 / 93$

1993/94

$1994 / 95$

$1995 / 96$

$1996 / 97$

\section{A. History of Trade Margins, 1988-1997}

Source: Deloitte and Touche (1997)

\begin{tabular}{|c|c|c|c|c|c|c|c|c|c|}
\hline & (\$/ton) & (\$/ton) & $(\$ /$ ton $)$ & $(\$ /$ ton $)$ & $(\$ /$ ton $)$ & $(\$ /$ ton $)$ & $(\$ /$ ton $)$ & (\$/ton) & $(\$ /$ ton $)$ \\
\hline Typical Farm Price & 284 & 269 & 399 & 309 & 237 & 186 & 340 & 321 & 349 \\
\hline Factory Gate Price & 433 & 390 & 636 & 429 & 271 & 335 & 423 & 413 & 480 \\
\hline Trade Margin (\%) (1) & $52 \%$ & $47 \%$ & $59 \%$ & $39 \%$ & $14 \%$ & $80 \%$ & $24 \%$ & $29 \%$ & $38 \%$ \\
\hline FOB Value Exports & & & & 585 & 689 & 697 & 675 & 790 & 713 \\
\hline Trade Margin (\%) (2) & & & & $36 \%$ & $154 \%$ & $108 \%$ & $60 \%$ & $91 \%$ & $49 \%$ \\
\hline
\end{tabular}

Based on inteviews conducted as part of the Rapid Rural Appraisal of Cashew Growing Areas in Gaza, Inhambane, and Nampula

\section{B. Farm and Factory Gate Prices for Raw Cashew Nuts}

Source: World Bank (1995b)

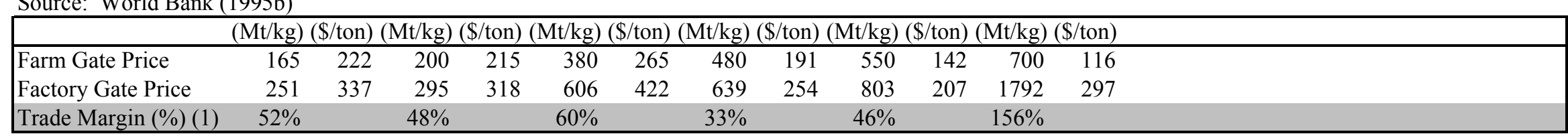

Data source: Secretary of State for Cashew, World Bank (1995b)

Note: The farm gate price used is the government-set price. As illustrated in Table 3.5, this price differed from the actual producer price beginning in 92/93.

The factory gate prices reflect government-set prices in 88/89-90/91; liberalized prices in 91/92 -92/93, and prices proposed by traders in 93/94.

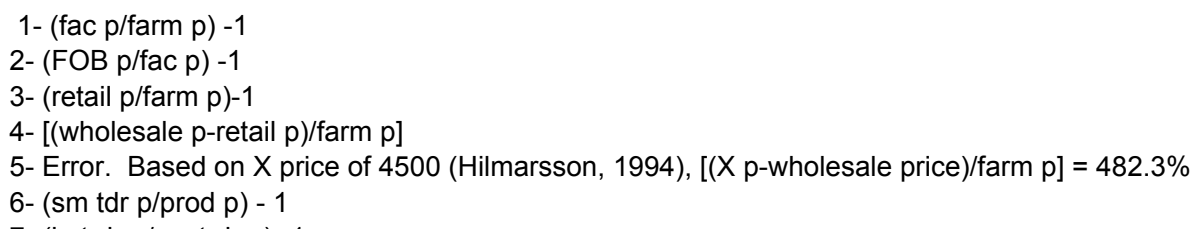


1988/89

$1989 / 90$

1990/91

$1991 / 92$

$1992 / 93$

$1993 / 94$

$1994 / 95$

$1995 / 96$

C. Price Structure and Trade Margins for 1993/94

Source: World Bank (1995b)

Farm-Gate Price (Mt/kg)

Farm-Gate Share of World Price

Farm-Gate Trade Margin (\%)

$15.5 \%$

Retailer to Warehouse Gate Price (Mt/kg) (3)

1124

Retailer to Warehouse Gate Share of World Price (3)

$24.9 \%$

Retailer to Warehouse Gate Trade Margin (\%) (3)

Wholesaler to Factory Gate Price (Mt/kg) (4)

Wholesaler to Factory Gate Share of World Price (4)

$60.6 \%$

Wholesaler to Factory Gate Trade Margin (\%) (4) $\quad 95.4 \%$

Wholesaler to Border Price (Mt/kg) (5)

$95.4 \%$
4200

Wholesaler to Border Share of World Price (5)

$00.0 \%$

Wholesaler to Border Trade Margin (\%) (5)

$482.3 \%$

Source: Secretary of State for Cashew, World Bank, $1995 b$

\section{Selling Prices at Trader Level, 1994-1997}

Source: Deloitte and Touche (1997)

\begin{tabular}{|c|c|c|c|}
\hline Small Trader Min. (Mt/kg) & 2500 & 4000 & 4000 \\
\hline Small Trader Max. (Mt/kg) & 4000 & 5500 & 6000 \\
\hline Typical Average (Mt/kg) & $3000-3500$ & $4500-5000$ & $4500-5000$ \\
\hline Small Trader Price Found (c/kg) & 52.9 & 41.3 & 43.6 \\
\hline Trade Margin (6) & $55.6 \%$ & $28.7 \%$ & $24.9 \%$ \\
\hline Large Trader Min. (Mt/kg) & 3000 & 4000 & 5000 \\
\hline Large Trader Max. (Mt/kg) & 5000 & 6000 & 6500 \\
\hline Typical Average (Mt/kg) & 4000 & 5000 & 5500 \\
\hline Large Trader Price Found (c/kg) & 60.4 & 45.8 & 48.0 \\
\hline Trade Margin (7) & $14.2 \%$ & $10.9 \%$ & $10.1 \%$ \\
\hline Producer Price Found (c/kg) & 34.0 & 32.1 & 34.9 \\
\hline
\end{tabular}

Based on inteviews conducted as part of the Rapid Rural Appraisal of Cashew Growing Areas in Gaza, Inhambane, and Nampula

1- (fac $\mathrm{p} / \mathrm{farm} \mathrm{p})-1$

2- (FOB p/fac $p)-1$

3- (retail p/farm $p)-1$

4- [(wholesale $p$-retail $p) /$ farm $p]$

5- Error. Based on $X$ price of 4500 (Hilmarsson, 1994), [(X p-wholesale price)/farm $p]=482.3 \%$

6- (sm tdr p/prod p) - 1

7- (lg trdr $\mathrm{p} / \mathrm{sm}$ trdr $\mathrm{p})$ - 
Table 5

World Market for Raw Cashew

\begin{tabular}{|c|c|c|c|c|c|c|c|c|c|c|c|c|}
\hline \multicolumn{13}{|c|}{ 1. Imports - Volume in Metric Tonnes Raw Cashews } \\
\hline Country & & 1990 & 1991 & 1992 & 1993 & 1994 & 1995 & 1996 & 1997 & 1998 & 1999 & 2000 \\
\hline World & & 123931 & 169309 & 174299 & 226978 & 253397 & 244811 & 37027 & 33050 & 48444 & 264074 & 263183 \\
\hline India & $84 \%$ & 82639 & 106080 & 134985 & 191322 & 228109 & 222819 & 19129 & 19431 & 38894 & 245106 & 249319 \\
\hline China & $4 \%$ & 7639 & 18538 & 20431 & 16454 & 7191 & 3065 & 1214 & 2764 & 1240 & 367 & 651 \\
\hline Singapore & $4 \%$ & 24606 & 26680 & 8447 & 5272 & 3150 & 3648 & 913 & 140 & 222 & 120 & 106 \\
\hline China, Hong Kong SAR & $3 \%$ & 4651 & 12827 & 8455 & 9665 & 5434 & 7205 & 240 & 823 & 393 & 551 & 313 \\
\hline Other & $5 \%$ & 4396 & 5184 & 1981 & 4264 & 9512 & 8074 & 15531 & 9891 & 7695 & 17930 & 12793 \\
\hline Brazil & $1 \%$ & 0 & 0 & 0 & 0 & 4548 & 1840 & 0 & 11 & 0 & 9639 & 6434 \\
\hline United States of America & $1 \%$ & 0 & 0 & 0 & 0 & 0 & 0 & 2855 & 3102 & 1515 & 1141 & 988 \\
\hline Canada & $1 \%$ & 355 & 80 & 116 & 447 & 648 & 409 & 1403 & 1601 & 1407 & 1457 & 1332 \\
\hline $\mathrm{HHI}$ & 7,069 & & & & & & & & & & & \\
\hline \multicolumn{13}{|c|}{ 2. Imports - Value in USD '000 Raw Cashews } \\
\hline Country & & 1990 & 1991 & 1992 & 1993 & 1994 & 1995 & 1996 & 1997 & 1998 & 1999 & 2000 \\
\hline World & & 135297 & 197414 & 198136 & 214173 & 291847 & 315580 & 85280 & 63232 & 70030 & 310411 & 246111 \\
\hline India & $70 \%$ & 75041 & 109340 & 143006 & 154464 & 221099 & 235625 & 17027 & 15722 & 36599 & 267529 & 213965 \\
\hline China, Hong Kong SAR & $6 \%$ & 13518 & 22189 & 18151 & 22996 & 21886 & 32624 & 330 & 718 & 201 & 423 & 139 \\
\hline Singapore & $5 \%$ & 22999 & 27411 & 12922 & 9693 & 12391 & 13833 & 1411 & 280 & 455 & 271 & 172 \\
\hline China & $3 \%$ & 5693 & 14482 & 16270 & 12856 & 13661 & 6033 & 589 & 2224 & 407 & 74 & 161 \\
\hline Israel & $2 \%$ & 3880 & 4429 & 3818 & 5083 & 6201 & 6838 & 6793 & 6868 & 6760 & 113 & 0 \\
\hline Canada & $2 \%$ & 998 & 263 & 401 & 1716 & 2684 & 2033 & 5137 & 7143 & 6573 & 8020 & 6983 \\
\hline Brazil & $1 \%$ & 0 & 0 & 0 & 0 & 3348 & 1382 & 0 & 22 & 0 & 8197 & 5470 \\
\hline Saudi Arabia & $1 \%$ & 0 & 2498 & 2501 & 2344 & 2803 & 1790 & 1852 & 2892 & 3205 & 3205 & 3205 \\
\hline Other & $6 \%$ & 759 & 1802 & 1067 & 5021 & 7774 & 15422 & 38864 & 13130 & 8357 & 15405 & 10372 \\
\hline $\mathrm{HHI}$ & 5,022 & & & & & & & & & & & \\
\hline \multicolumn{13}{|c|}{ 3. Exports - Volume in Metric Tonnes Raw Cashews } \\
\hline Country & & 1990 & 1991 & 1992 & 1993 & 1994 & 1995 & 1996 & 1997 & 1998 & 1999 & 2000 \\
\hline World & & 110115 & 154126 & 166231 & 172279 & 283951 & 220223 & 232007 & 329762 & 327785 & 288637 & 327056 \\
\hline Tanzania, United Rep of & $32 \%$ & 4197 & 19000 & 29300 & 32200 & 65000 & 75560 & 118360 & 121920 & 164680 & 99990 & 99990 \\
\hline Guinea-Bissau & $14 \%$ & 16409 & 18250 & 3650 & 16990 & 46460 & 29280 & 13000 & 58080 & 38800 & 64050 & 73210 \\
\hline Viet Nam & $14 \%$ & 24749 & 30600 & 51700 & 47700 & 81300 & 19800 & 16500 & 33299 & 25700 & 18400 & 26400 \\
\hline Indonesia & $10 \%$ & 3218 & 14602 & 19278 & 18156 & 38620 & 28105 & 27206 & 15359 & 28603 & 31639 & 25621 \\
\hline Côte d'Ivoire & $9 \%$ & 6325 & 7415 & 7675 & 16862 & 16327 & 26345 & 9739 & 36968 & 26553 & 25000 & 63379 \\
\hline Nigeria & $6 \%$ & 12415 & 12600 & 12109 & 13238 & 14785 & 15581 & 16829 & 16900 & 11357 & 11357 & 11357 \\
\hline Singapore & $3 \%$ & 26116 & 26401 & 11403 & 6185 & 4837 & 3010 & 920 & 2462 & 2631 & 1260 & 1044 \\
\hline Benin & $3 \%$ & 1200 & 2085 & 3378 & 3378 & 3378 & 8940 & 15000 & 20000 & 8940 & 8940 & 8940 \\
\hline China, Hong Kong SAR & $2 \%$ & 2948 & 10383 & 8023 & 7782 & 4468 & 5240 & 1044 & 16 & 429 & 401 & 16 \\
\hline Ghana & $1 \%$ & 0 & 0 & 0 & 0 & 600 & 289 & 895 & 7042 & 1351 & 3963 & 3963 \\
\hline Philippines & $1 \%$ & 2622 & 3646 & 3098 & 3119 & 1152 & 1122 & 302 & 555 & 2142 & 8 & 0 \\
\hline Other & $2 \%$ & 8510 & 4695 & 11943 & 3345 & 2511 & 2497 & 4647 & 3116 & 3016 & 4121 & 5478 \\
\hline Guinea & $1 \%$ & 2100 & 700 & 3700 & 1000 & 1000 & 1000 & 1000 & 1000 & 1000 & 1000 & 1000 \\
\hline Thailand & $1 \%$ & 5636 & 2659 & 3334 & 860 & 57 & 70 & 5 & 531 & 535 & 214 & 63 \\
\hline $\mathrm{HHI}$ & 1,671 & & & & & & & & & & & \\
\hline
\end{tabular}


Table 5

World Market for Raw Cashew

\begin{tabular}{|c|c|c|c|c|c|c|c|c|c|c|c|c|}
\hline \multicolumn{13}{|c|}{ 4. Exports - Value in USD '000 Raw Cashews } \\
\hline Country & & 1990 & 1991 & 1992 & 1993 & 1994 & 1995 & 1996 & 1997 & 1998 & 1999 & 2000 \\
\hline World & & 84133 & 134926 & 142915 & 130465 & 225659 & 189613 & 207717 & 390192 & 352165 & 378147 & 460169 \\
\hline Viet Nam & $26 \%$ & 14917 & 21100 & 41415 & 29700 & 54500 & 13400 & 11000 & 133331 & 116954 & 109747 & 157000 \\
\hline Tanzania, United Rep of & $25 \%$ & 3949 & 16700 & 23500 & 23300 & 51160 & 64000 & 97770 & 91080 & 107320 & 98940 & 98940 \\
\hline Guinea-Bissau & $11 \%$ & 11605 & 14071 & 3010 & 12980 & 30970 & 19870 & 16332 & 45289 & 23901 & 49440 & 69349 \\
\hline Indonesia & $10 \%$ & 8243 & 24560 & 24854 & 23144 & 43401 & 21308 & 20800 & 15386 & 28706 & 30774 & 22781 \\
\hline India & $6 \%$ & 0 & 0 & 0 & 0 & 0 & 0 & 21616 & 52115 & 28032 & 26040 & 37919 \\
\hline Côte d'Ivoire & $6 \%$ & 4026 & 4374 & 4795 & 6598 & 6029 & 18936 & 6999 & 21187 & 18991 & 20000 & 41655 \\
\hline Singapore & $3 \%$ & 21146 & 26167 & 11665 & 6025 & 8460 & 9316 & 1529 & 2447 & 2152 & 1524 & 931 \\
\hline China, Hong Kong SAR & $3 \%$ & 6914 & 12226 & 10414 & 13785 & 14962 & 23569 & 1021 & 26 & 256 & 306 & 12 \\
\hline Nigeria & $3 \%$ & 4039 & 4442 & 5461 & 7024 & 7845 & 10233 & 11100 & 10500 & 7100 & 7100 & 7100 \\
\hline Benin & $1 \%$ & 900 & 754 & 1060 & 1060 & 1060 & 2800 & 4800 & 6400 & 2800 & 2800 & 2800 \\
\hline Senegal & $1 \%$ & 0 & 964 & 708 & 775 & 767 & 1038 & 1428 & 1469 & 6003 & 13131 & 19 \\
\hline Other & $5 \%$ & 8394 & 9562 & 16033 & 6074 & 6497 & 5143 & 13315 & 10956 & 9949 & 18331 & 21650 \\
\hline Kenya & $1 \%$ & 48 & 209 & 423 & 58 & 1395 & 80 & 1 & 128 & 1624 & 7904 & 7904 \\
\hline Guinea & $1 \%$ & 1700 & 700 & 4200 & 1100 & 1100 & 1100 & 1100 & 1100 & 1100 & 1100 & 1100 \\
\hline $\mathrm{HHI}$ & 1,653 & & & & & & & & & & & \\
\hline
\end{tabular}




\section{Table 6}

World Market for Processed Cashew

\begin{tabular}{|c|c|c|c|c|c|c|c|c|c|c|c|c|}
\hline \multicolumn{13}{|c|}{ 1. Imports-Volume in Metric Tonnes Processed Cashews } \\
\hline Country & & 1990 & 1991 & 1992 & 1993 & 1994 & 1995 & 1996 & 1997 & 1998 & 1999 & 2000 \\
\hline World & & 87098 & 85383 & 103163 & 107506 & 116785 & 114671 & 323196 & 370346 & 352411 & 152679 & 158088 \\
\hline United States of America & $34 \%$ & 54453 & 49433 & 61069 & 59937 & 61714 & 53800 & 58232 & 63354 & 64405 & 71565 & 81508 \\
\hline India & $32 \%$ & 0 & 0 & 0 & 0 & 0 & 0 & 193722 & 226781 & 204459 & 10893 & 388 \\
\hline Netherlands & $8 \%$ & 4088 & 4644 & 6642 & 8537 & 13486 & 15915 & 17347 & 19024 & 18835 & 19316 & 20494 \\
\hline Canada & $3 \%$ & 4376 & 4747 & 4951 & 5562 & 4780 & 4153 & 4542 & 3633 & 4245 & 3735 & 4830 \\
\hline Germany & $4 \%$ & 3732 & 4008 & 5513 & 7219 & 8573 & 9959 & 8745 & 11436 & 12975 & 4968 & 6081 \\
\hline United Kingdom & $3 \%$ & 5108 & 4808 & 5756 & 6495 & 6120 & 5603 & 6145 & 6260 & 6743 & 7905 & 8043 \\
\hline Japan & $3 \%$ & 4298 & 5530 & 4892 & 5621 & 5665 & 6413 & 6548 & 6526 & 5532 & 4886 & 5660 \\
\hline Australia & $3 \%$ & 2920 & 2619 & 3371 & 3126 & 3749 & 5500 & 5116 & 6700 & 6300 & 5629 & 5260 \\
\hline France & $2 \%$ & 1212 & 1425 & 1586 & 2075 & 2321 & 3243 & 3891 & 4500 & 6922 & 4639 & 4470 \\
\hline Italy & $1 \%$ & 307 & 356 & 476 & 718 & 901 & 1116 & 1186 & 1708 & 1713 & 1866 & 2075 \\
\hline United Arab Emirates & $1 \%$ & 1700 & 1899 & 1882 & 536 & 850 & 17 & 2380 & 2380 & 2380 & 2380 & 2380 \\
\hline China & $1 \%$ & 1277 & 1343 & 1303 & 1422 & 988 & 972 & 1712 & 1717 & 1194 & 1087 & 856 \\
\hline Other & $6 \%$ & 3627 & 4571 & 5722 & 6258 & 7638 & 7980 & 13630 & 16327 & 16709 & 13811 & 16044 \\
\hline $\mathrm{HHI}$ & 2,377 & & & & & & & & & & & \\
\hline \multicolumn{13}{|c|}{ 2. Imports-Value in USD '000 Processed Cashews } \\
\hline Country & & 1990 & 1991 & 1992 & 1993 & 1994 & 1995 & 1996 & 1997 & 1998 & 1999 & 2000 \\
\hline World & & 389004 & 445548 & 477411 & 474310 & 547994 & 561327 & 829672 & 865436 & 884410 & 840402 & 856548 \\
\hline United States of America & $46 \%$ & 236306 & 253551 & 269675 & 253748 & 283127 & 253050 & 293394 & 301346 & 307360 & 431335 & 449800 \\
\hline Netherlands & $11 \%$ & 18962 & 24055 & 34468 & 41349 & 65206 & 81308 & 89868 & 95232 & 93552 & 117999 & 118008 \\
\hline Germany & $6 \%$ & 18266 & 20987 & 29026 & 34535 & 43635 & 52752 & 46680 & 58681 & 58473 & 26483 & 33681 \\
\hline Japan & $5 \%$ & 21959 & 32584 & 25919 & 27947 & 28852 & 34025 & 36401 & 33920 & 28778 & 31389 & 32718 \\
\hline United Kingdom & $5 \%$ & 23227 & 27162 & 26921 & 29273 & 29586 & 26738 & 32459 & 30185 & 33600 & 50282 & 44982 \\
\hline India & $8 \%$ & 0 & 0 & 0 & 0 & 0 & 0 & 175493 & 191419 & 195904 & 10790 & 331 \\
\hline Canada & $3 \%$ & 20553 & 25215 & 21530 & 24567 & 23061 & 20709 & 22627 & 16701 & 19321 & 20554 & 23645 \\
\hline Australia & $3 \%$ & 13935 & 12879 & 17803 & 14410 & 16640 & 30286 & 25522 & 27018 & 25448 & 34398 & 26717 \\
\hline France & $2 \%$ & 5339 & 7212 & 7636 & 8528 & 10911 & 13937 & 17544 & 19732 & 28161 & 21512 & 22800 \\
\hline United Arab Emirates & $1 \%$ & 7800 & 10529 & 8331 & 2214 & 4146 & 88 & 11792 & 11792 & 11792 & 11792 & 11792 \\
\hline China & $1 \%$ & 6248 & 6726 & 6674 & 6763 & 4631 & 4696 & 7594 & 6651 & 4292 & 4537 & 3740 \\
\hline Italy & $1 \%$ & 800 & 1225 & 1910 & 2200 & 3076 & 4453 & 4896 & 6980 & 8024 & 10068 & 10801 \\
\hline China, Hong Kong SAR & $1 \%$ & 0 & 0 & 0 & 0 & 0 & 0 & 14886 & 14087 & 17290 & 7920 & 6430 \\
\hline Other & $0 \%$ & & & & & & & & & & & \\
\hline $\mathrm{HHI}$ & 2,454 & & & & & & & & & & & \\
\hline
\end{tabular}




\section{Table 6}

World Market for Processed Cashew

\begin{tabular}{|c|c|c|c|c|c|c|c|c|c|c|c|c|}
\hline \multicolumn{13}{|c|}{ 3. Exports Volume in Metric Tonnes Processed Cashews } \\
\hline Country & & 1990 & 1991 & 1992 & 1993 & 1994 & 1995 & 1996 & 1997 & 1998 & 1999 & 2000 \\
\hline World & & 91338 & 83904 & 107979 & 111951 & 118737 & 136145 & 137141 & 158136 & 153323 & 161040 & 175657 \\
\hline India & $52 \%$ & 49812 & 49908 & 58399 & 69832 & 76897 & 70068 & 64274 & 65809 & 71042 & 92222 & 81661 \\
\hline Brazil & $24 \%$ & 27103 & 24121 & 38097 & 31170 & 23079 & 31877 & 36222 & 36349 & 31882 & 24101 & 33588 \\
\hline Mozambique & $3 \%$ & 4300 & 3800 & 5500 & 2300 & 5000 & 2000 & 3600 & 4100 & 4700 & 4700 & 4700 \\
\hline Viet Nam & $10 \%$ & 0 & 0 & 0 & 0 & 0 & 19800 & 16500 & 33300 & 25700 & 18400 & 34200 \\
\hline Netherlands & $4 \%$ & 990 & 885 & 992 & 3182 & 7823 & 6684 & 6723 & 6838 & 8168 & 11271 & 10295 \\
\hline Kenya & $0 \%$ & 394 & 1236 & 342 & 44 & 158 & 81 & 0 & 245 & 35 & 71 & 71 \\
\hline Tanzania, United Rep of & $0 \%$ & 907 & 0 & 0 & 0 & 0 & 0 & 0 & 0 & 0 & 0 & 0 \\
\hline Other & $6 \%$ & 7832 & 5954 & 4649 & 5423 & 5780 & 5635 & 9822 & 11495 & 11796 & 10275 & 11142 \\
\hline $\mathrm{HHI}$ & 3,458 & & & & & & & & & & & \\
\hline India's Share & & $55 \%$ & $59 \%$ & $54 \%$ & $62 \%$ & $65 \%$ & $51 \%$ & $47 \%$ & $42 \%$ & $46 \%$ & $57 \%$ & $46 \%$ \\
\hline Mozambique's Share & & $5 \%$ & $5 \%$ & $5 \%$ & $2 \%$ & $4 \%$ & $1 \%$ & $3 \%$ & $3 \%$ & $3 \%$ & $3 \%$ & $3 \%$ \\
\hline \multicolumn{13}{|c|}{ 4. Exports Value in USD '000 Processed Cashews } \\
\hline Country & & 1990 & 1991 & 1992 & 1993 & 1994 & 1995 & 1996 & 1997 & 1998 & 1999 & 2000 \\
\hline World & & 402859 & 438950 & 474258 & 500965 & 593750 & 603240 & 599718 & 573384 & 763608 & 944402 & 867491 \\
\hline India & $58 \%$ & 247183 & 246221 & 283043 & 334499 & 398287 & 383068 & 338320 & 325879 & 362560 & 570595 & 418488 \\
\hline Brazil & $22 \%$ & 101351 & 110685 & 146441 & 119896 & 109200 & 147236 & 167508 & 156917 & 142575 & 142125 & 165059 \\
\hline Mozambique & $2 \%$ & 14288 & 16033 & 17592 & 8151 & 18000 & 7000 & 13000 & 12000 & 15000 & 15000 & 15000 \\
\hline Viet Nam & $6 \%$ & 0 & 0 & 0 & 0 & 0 & 0 & 0 & 0 & 154000 & 109748 & 167323 \\
\hline Netherlands & $5 \%$ & 3829 & 3684 & 4444 & 15148 & 38927 & 39231 & 41100 & 37665 & 41685 & 61121 & 53055 \\
\hline Kenya & $0 \%$ & 1379 & 5061 & 1052 & 109 & 548 & 317 & 0 & 986 & 166 & 328 & 328 \\
\hline Tanzania, United Rep of & $0 \%$ & 3272 & 0 & 0 & 0 & 0 & 0 & 0 & 0 & 0 & 0 & 0 \\
\hline United States of America & $1 \%$ & 9853 & 9016 & 5972 & 9828 & 10042 & 5767 & 5643 & 3038 & 5026 & 6093 & 5625 \\
\hline Sri Lanka & $1 \%$ & 6926 & 6950 & 5439 & 4313 & 991 & 2109 & 1328 & 3074 & 2273 & 999 & 999 \\
\hline Other & $4 \%$ & 14778 & 12204 & 10275 & 9021 & 17755 & 18512 & 32819 & 33825 & 40323 & 38393 & 41613 \\
\hline $\mathrm{HHI}$ & 3,926 & & & & & & & & & & & \\
\hline
\end{tabular}


Table 7

Mozambican Exports of Cashew by Importer, 1980-1997

\begin{tabular}{|c|c|c|c|c|c|}
\hline Year & Importing country & \begin{tabular}{|l|} 
(thousands \$) \\
\end{tabular} & Year & Importing country & (thousands \$) \\
\hline 1980 & United States & 38422 & 1991 & Ireland & 11 \\
\hline 1980 & Canada & 1025 & 1991 & Austria & 6 \\
\hline 1980 & Hong Kong & 176 & 1991 & Finland & 6 \\
\hline 1980 & Trinidad-Tobago & 156 & 1991 & Sweden & 5 \\
\hline 1980 & Cyprus & 54 & 1992 & India & 13256 \\
\hline 1981 & United States & 46460 & 1992 & United States & 11432 \\
\hline 1981 & Japan & 963 & 1992 & South Africa & 944 \\
\hline 1981 & Canada & 452 & 1992 & Portugal & 869 \\
\hline 1981 & Trinidad-Tobago & 439 & 1992 & Germany & 476 \\
\hline 1981 & Syrn Arab RP & 130 & 1992 & France & 332 \\
\hline 1982 & United States & 38880 & 1992 & Netherlands & 220 \\
\hline 1982 & Japan & 505 & 1992 & United Kingdom & 97 \\
\hline 1982 & Canada & 219 & 1992 & Switzerland & 68 \\
\hline 1982 & Trinidad-Tobago & 161 & 1992 & Belgium-Lux & 42 \\
\hline 1982 & Jordan & 34 & 1992 & Canada & 39 \\
\hline 1983 & United States & 12428 & 1992 & Spain & 18 \\
\hline 1983 & Canada & 73 & 1992 & Sweden & 18 \\
\hline 1983 & Trinidad-Tobago & 20 & 1992 & Austria & 13 \\
\hline 1983 & Belgium-Lux & 10 & 1992 & Ireland & 10 \\
\hline 1984 & United States & 9559 & 1992 & Denmark (inc. Faroe Is) & 6 \\
\hline 1984 & Canada & 204 & 1993 & India & 14341 \\
\hline 1984 & Cyprus & 33 & 1993 & United States & 6610 \\
\hline 1984 & Belgium-Lux & 15 & 1993 & South Africa & 1429 \\
\hline 1985 & United States & 9163 & 1993 & Portugal & 625 \\
\hline 1985 & Canada & 45 & 1993 & Canada & 296 \\
\hline 1986 & United States & 7401 & 1993 & Netherlands & 235 \\
\hline 1987 & United States & 16369 & 1993 & United Kingdom & 230 \\
\hline 1988 & United States & 14396 & 1993 & France & 118 \\
\hline 1988 & Canada & 681 & 1993 & Switzerland & 114 \\
\hline 1988 & Guadeloupe (inc. Martinique) & 65 & 1993 & Germany & 76 \\
\hline 1989 & United States & 9457 & 1993 & Italy & 33 \\
\hline 1989 & Canada & 258 & 1993 & China & 23 \\
\hline 1989 & Cuba & 187 & 1993 & Ireland & 10 \\
\hline 1990 & United States & 10897 & 1993 & Sweden & 10 \\
\hline 1990 & Germany & 1231 & 1993 & Finland & 5 \\
\hline 1990 & Australia & 823 & 1994 & India & 10819 \\
\hline 1990 & United Kingdom & 477 & 1994 & South Africa & 2670 \\
\hline 1990 & Portugal & 424 & 1994 & United States & 1706 \\
\hline 1990 & Canada & 233 & 1994 & Malaysia & 307 \\
\hline 1990 & Belgium-Lux & 51 & 1994 & United Kingdom & 141 \\
\hline 1990 & Sweden & 48 & 1994 & Portugal & 58 \\
\hline 1990 & Czechoslovakia & 29 & 1995 & United States & 5300 \\
\hline 1990 & France & 22 & 1995 & India & 4607 \\
\hline 1990 & Netherlands & 12 & 1995 & South Africa & 2208 \\
\hline 1990 & Austria & 11 & 1995 & Portugal & 567 \\
\hline 1990 & Finland & 11 & 1995 & Netherlands & 130 \\
\hline 1990 & Ireland & 8 & 1996 & India & 25739 \\
\hline 1990 & Denmark (inc. Faroe Is) & 7 & 1996 & United States & 13560 \\
\hline 1991 & United States & 11526 & 1996 & Portugal & 1864 \\
\hline 1991 & India & 1598 & 1996 & South Africa & 1642 \\
\hline 1991 & Portugal & 955 & 1996 & Areas Nes (?) & 784 \\
\hline 1991 & United Kingdom & 429 & 1996 & Canada & 520 \\
\hline 1991 & Germany & 393 & 1996 & Singapore & 311 \\
\hline 1991 & Canada & 383 & 1996 & France & 92 \\
\hline 1991 & Australia & 371 & 1996 & Zimbabwe & 12 \\
\hline 1991 & Netherlands & 92 & 1997 & United States & 12522 \\
\hline 1991 & Switzerland & 54 & 1997 & Canada & 774 \\
\hline 1991 & Belgium-Lux & 47 & 1997 & Portugal & 745 \\
\hline 1991 & France & 46 & 1997 & France & 143 \\
\hline 1991 & Denmark (inc. Faroe Is) & 15 & 1997 & Netherlands & 92 \\
\hline 1991 & Japan & 13 & 1997 & Zimbabwe & 32 \\
\hline 1991 & Norway & 12 & 1997 & Denmark (inc. Faroe Is) & 6 \\
\hline
\end{tabular}

Source:

Feenstra (2000): World Trade Flows, 1980-1997 


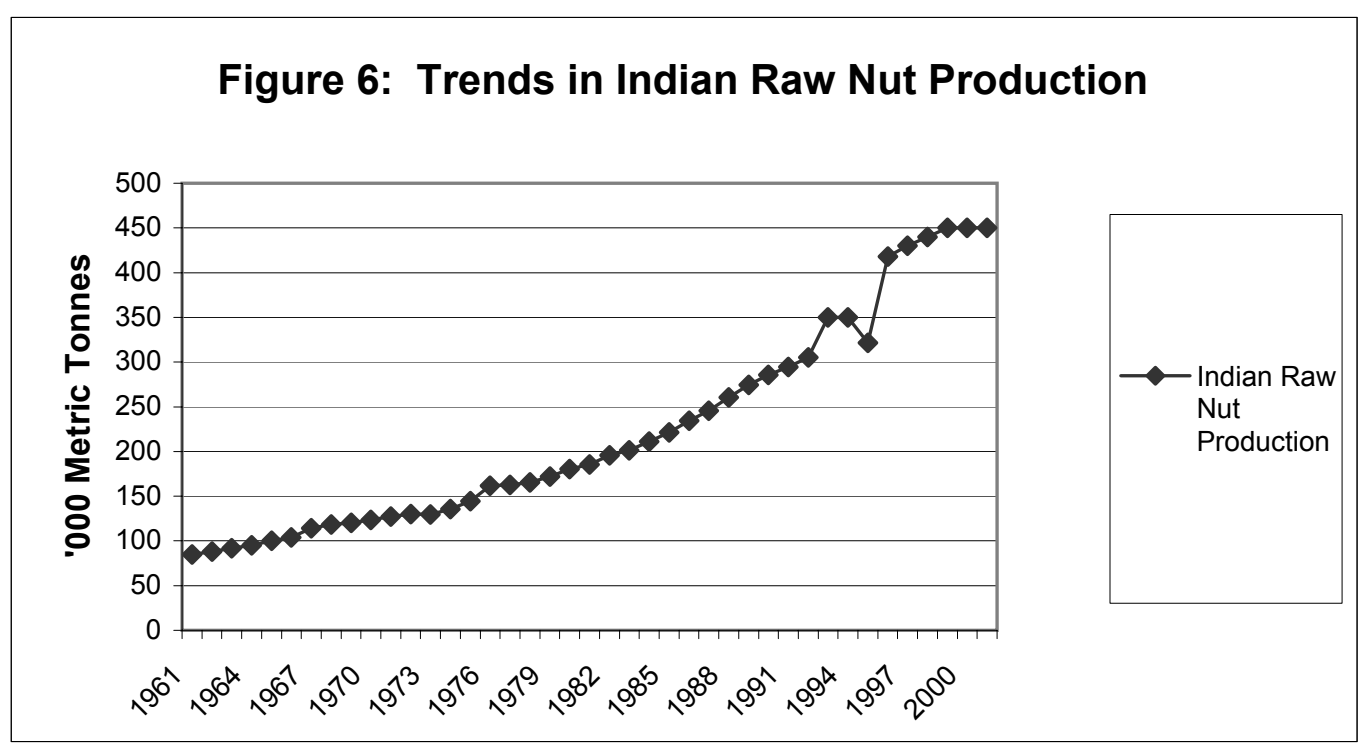




\section{Table 8}

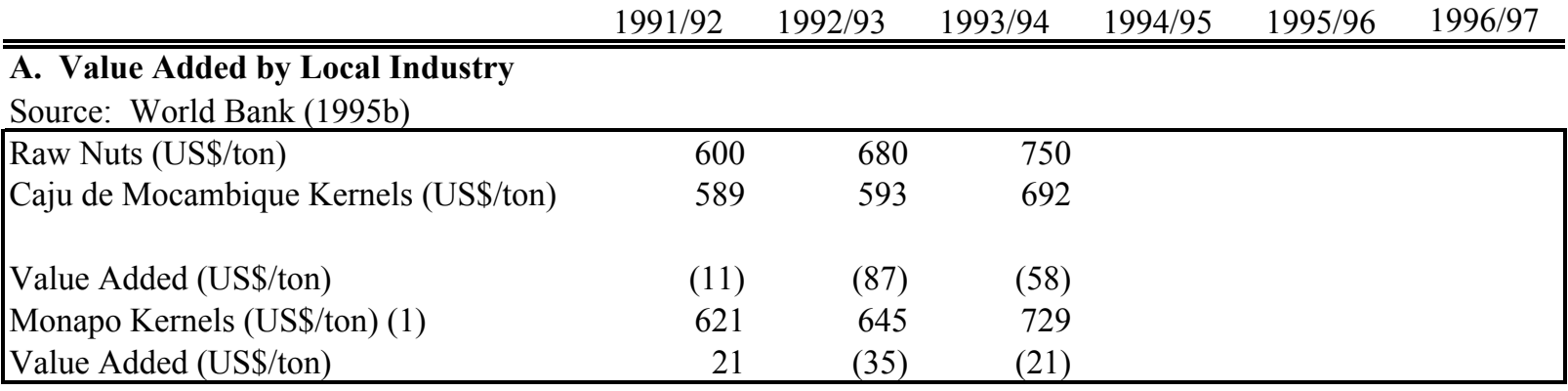

Note: kernel RCN equivalent (conversion factor) for Caju de Mocambique is 5.40 and for Monapo is 5.13

Source: Secretary of State for Cashew

\section{B. Value Added by Mozambican Industry}

Source: Deloitte and Touche (1997)

\begin{tabular}{|lrrr|}
\hline FOB Price of Raw Nuts (US\$/ton) & 675 & 790 & 713 \\
Average Kernel Price (US\$/ton) & 3734 & 3876 & 3680 \\
Raw Nut Equivalent (2) (US\$/ton) & 765 & 795 & 754 \\
Value Added & 90 & 5 & 41 \\
\hline
\end{tabular}




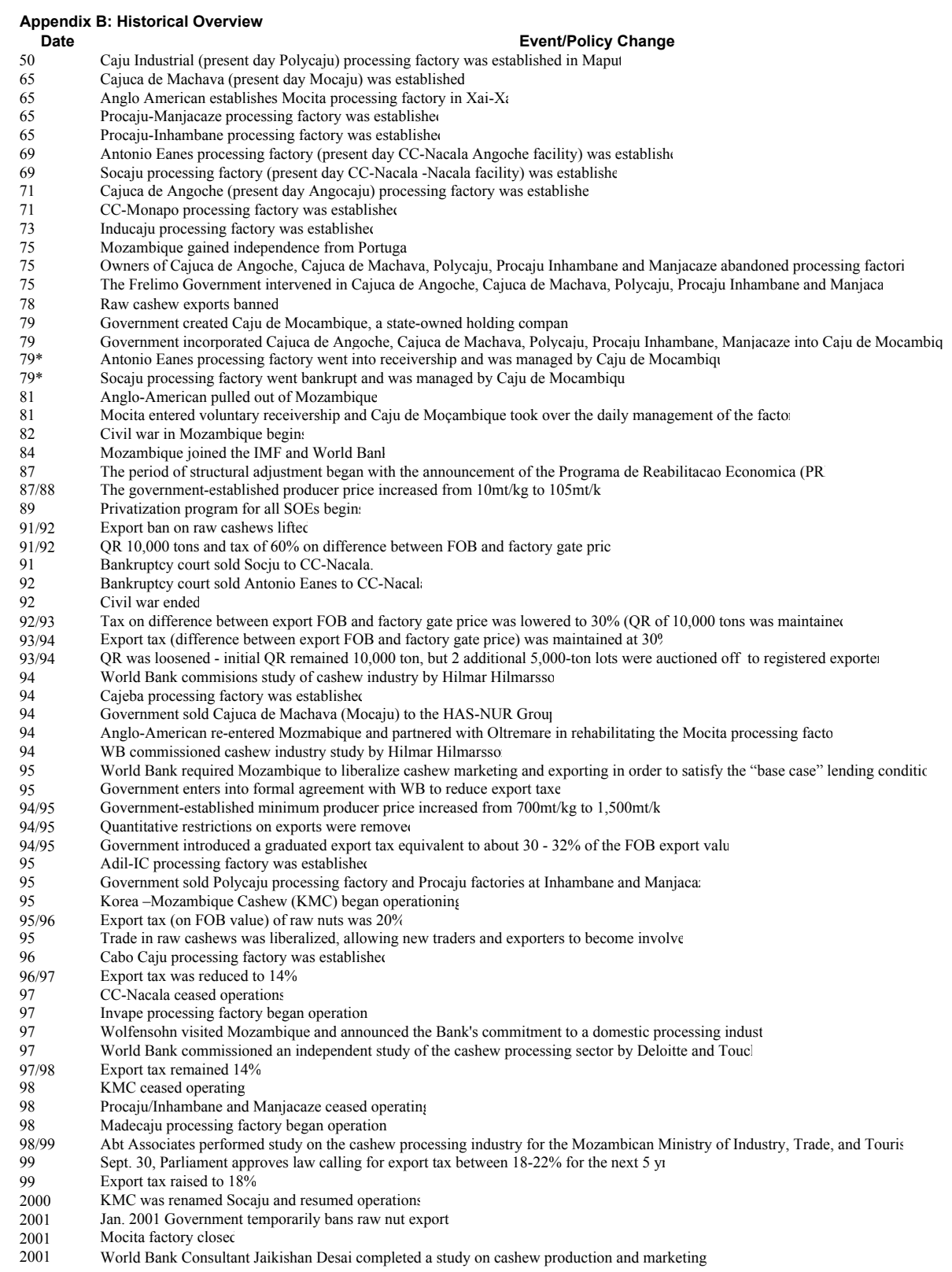




\begin{tabular}{|c|c|c|c|c|c|c|c|c|c|c|c|c|}
\hline Year & Source & 1961 & 1962 & 1963 & 1964 & 1965 & 1966 & 1967 & 1968 & 1969 & 1970 & 1971 \\
\hline Export Policy/Tax on FOB & Various & & & & & & & & & & & \\
\hline \multicolumn{13}{|l|}{ Production } \\
\hline Area Harvested Ha. & FAO & 180,000 & 180,000 & 230,000 & 230,000 & 210,000 & 190,000 & 180,000 & 300,000 & 250,000 & 290,000 & 320,000 \\
\hline Yield kg/ha & FAO & 5,944 & 6,000 & 6,478 & 6,783 & 6,476 & 6,263 & 5,611 & 6,197 & 6,168 & 6,345 & 6,312 \\
\hline Production (tons) & FAO & 107,000 & 108,000 & 149,000 & 156,000 & 136,000 & 119,000 & 101,000 & 185,000 & 154,200 & 184,000 & 202,000 \\
\hline Marketed Raw Cashews (tons) & (1) & & & & & 120,000 & 110,000 & 95,000 & 120,000 & 160,000 & 150,000 & 175,000 \\
\hline \multicolumn{13}{|l|}{ Processing } \\
\hline Raw Cashews Processed (tons) & (1) & & & & & & & & & & & \\
\hline \multicolumn{13}{|l|}{ Processed Nuts as $\%$ of Marketed Vol. } \\
\hline \multicolumn{13}{|l|}{ Exports } \\
\hline Number of Exporters & (2) & & & & & & & & & & & \\
\hline Exported Raw Cashew (tons) & (1) & & & & & & & & & & & \\
\hline Kernel Exports (tons) & (1) & & & & & & & & & & & \\
\hline Raw Cashew Exports (Mt.) & FAO & 89,583 & 107,000 & 124,210 & 141,808 & 119,136 & 77,235 & 56,192 & 132,857 & 68,532 & 66,252 & 53,382 \\
\hline Raw Cashew VX ('000 \$) & FAO & 11,601 & 13,857 & 16,085 & 18,364 & 15,428 & 15,183 & 10,734 & 24,264 & 13,898 & 14,044 & 11,788 \\
\hline Shelled Cashew (Kernel) Exports (Mt.) & FAO & 2,000 & 2,000 & 2,000 & 2,000 & 2,500 & 5,861 & 8,190 & 11,646 & 13,047 & 15,071 & 20,395 \\
\hline Shelled Cashew (Kernel) Value Exports ('000 \$) & FAO & 1,800 & 1,800 & 1,800 & 1,800 & 2,300 & 5,649 & 7,778 & 12,643 & 13,310 & 16,211 & 23,602 \\
\hline Value of Exports (Raw and Processed, '000\$) & UCDavis & & & & & & & & & & & \\
\hline \multicolumn{13}{|l|}{ Prices } \\
\hline Government-Established Producer price (Mt $/ \mathrm{kg})$ & (6) & & & & & & 2.25 & 2.33 & 2.39 & 2.51 & 2.65 & 3.01 \\
\hline Actual Producer price (Mt $/ \mathrm{kg})$ & (7) & & & & & & & & & & & \\
\hline Actual Producer price (Mt $/ \mathrm{kg}$ ) & (8) & & & & & & & & & & & \\
\hline Real Producer Price (Mt/kg) & (9) & & & & & & & & & & & \\
\hline \multicolumn{13}{|l|}{ Producer price US\$/ton@ @ OR } \\
\hline \multicolumn{13}{|l|}{ Producer price US\$/ton @ PR } \\
\hline FOB price $(\$$ /ton) raw nuts & (8) & & & & & & & & & & & \\
\hline Producer/ FOB official rates & (8) & & & & & & & & & & & \\
\hline Producer/ FOB parallel rates & (8) & & & & & & & & & & & \\
\hline Export Unit Value Raw Cashews (\$/ton) & FAO & 130 & 130 & 129 & 129 & 129 & 197 & 191 & 183 & 203 & 212 & 221 \\
\hline Factory gate price $(\$ /$ ton $)$ & (8) & & & & & & & & & & & \\
\hline Export Unit Value Shelled Cashew (\$/ton) & FAO & 900 & 900 & 900 & 900 & 920 & 964 & 950 & 1086 & 1020 & 1076 & 1157 \\
\hline \multicolumn{13}{|l|}{ Macro data } \\
\hline Inflation & (10) & & & & & & & & & & & \\
\hline CPI & (10) & & & & & & & & & & & \\
\hline Parallel Market Exchange Rate (Mt/\$) & (11) & & & & & & & & & & & \\
\hline Official Exchange Rate (Mt/\$) & (11) & 28.75 & 28.75 & 28.75 & 28.75 & 28.75 & 28.75 & 28.75 & 28.75 & 28.75 & 28.75 & 29.6 \\
\hline GDP (billions of Meticais) & (12) & & & & & & & & & & & \\
\hline & & & & & & & & & & & & \\
\hline \multicolumn{13}{|l|}{ Notes } \\
\hline \multicolumn{13}{|l|}{ (1) Deloitte and Touche (1997); INCAJU (2001) } \\
\hline \multicolumn{13}{|l|}{ (2) Deloitte and Touche (1997) } \\
\hline \multirow{2}{*}{\multicolumn{13}{|c|}{$\begin{array}{l}\text { (3) QR } 10,000,60 \% \operatorname{tax} \text { (FOB-factory gate price) } \\
\text { (4) } \mathrm{QR} 10,000,30 \% \operatorname{tax} \text { (FOB-factory gate price) }\end{array}$}} \\
\hline \multirow{2}{*}{\multicolumn{13}{|c|}{$\begin{array}{l}\text { (4) QR } 10,000,30 \% \text { tax (FOB-factory gate price) } \\
\text { (5) QR } 10,000+, 30 \% \text { tax (FOB-factory gate price) }\end{array}$}} \\
\hline & & & & & & & & & & & & \\
\hline (6) INCAJU (2001) FAO pre-78. & & & & & & & & & & & & \\
\hline
\end{tabular}




\begin{tabular}{|c|c|c|c|c|c|c|c|c|c|c|c|c|}
\hline Year & & 1972 & 1973 & 1974 & 1975 & 1976 & 1977 & 1978 & $1978 / 79$ & $1979 / 80$ & $1980 / 81$ & $1981 / 82$ \\
\hline Export Policy/Tax on FOB & Various & & & & & & & banned & banned & banned & banned & banned \\
\hline \multicolumn{13}{|l|}{ Production } \\
\hline Area Harvested Ha. & FAO & 320,000 & 360,000 & 340,000 & 300,000 & 200,000 & 150,000 & 110,000 & 120,000 & 130,000 & 130,000 & 110,000 \\
\hline Yield kg/ha & FAO & 6,250 & 6,667 & 6,276 & 6,267 & 6,100 & 6,100 & 5,545 & 5,500 & 5,469 & 5,469 & 5,545 \\
\hline Production (tons) & FAO & 200,000 & 240,000 & 213,000 & 188,000 & 122,000 & 91,500 & 61,00 & 66,00 & 71,100 & 71,100 & 61,000 \\
\hline Marketed Raw Cashews (tons) & (1) & 215,000 & 200,000 & 195,000 & 170,000 & 125,000 & 110,000 & 80,000 & 82,800 & 84,700 & 91,466 & 57,323 \\
\hline \multicolumn{13}{|l|}{ Processing } \\
\hline Raw Cashews Processed (tons) & (1) & & & & & & & & & & & \\
\hline \multicolumn{13}{|l|}{ Processed Nuts as \% of Marketed Vol. } \\
\hline \multicolumn{13}{|l|}{ Exports } \\
\hline Number of Exporters & (2) & & & & & & & & & & & \\
\hline Exported Raw Cashew (tons) & (1) & & & & & banned & banned & banned & banned & banned & banned & banned \\
\hline Kernel Exports (tons) & (1) & & & & & & & & & & & \\
\hline Raw Cashew Exports (Mt.) & FAO & 67,527 & 33,195 & 72,899 & 65,592 & 13,815 & & & & & & \\
\hline Raw Cashew VX ('000 \$) & FAO & 14,108 & 8,422 & 17,606 & 17,310 & 2,487 & & & & & & \\
\hline Shelled Cashew (Kernel) Exports (Mt.) & FAO & 26,993 & 29,960 & 24,750 & 22,025 & 21,153 & 17,000 & 18,400 & 17,100 & 15,600 & 12,200 & 16,700 \\
\hline Shelled Cashew (Kernel) Value Exports ('000 \$) & FAO & 30,103 & 41,690 & 42,935 & 31,402 & 33,400 & 45,557 & 43,723 & 44,189 & 64,855 & 53,468 & 43,607 \\
\hline Value of Exports (Raw and Processed, '000\$) & UCDavis & & & & & & & & & 39,833 & 48,444 & 39,799 \\
\hline \multicolumn{13}{|l|}{ Prices } \\
\hline Government-Established Producer price (Mt $/ \mathrm{kg})$ & (6) & 3.43 & 3.53 & 3.74 & 4.01 & 5.5 & 6.6 & 3.5 & 3.5 & 3.5 & 3.5 & 5.0 \\
\hline Actual Producer price (Mt/kg) & (7) & & & & & & & & 3.5 & 3.5 & 3.5 & 5.0 \\
\hline Actual Producer price (Mt $/ \mathrm{kg})$ & (8) & & & & & 3.5 & 3.5 & 3.5 & 3.5 & 3.5 & 3.5 & 5.0 \\
\hline Real Producer Price (Mt/kg) & (9) & & & & & 55.0 & 54.5 & 53.4 & 52.9 & 51.8 & 51.3 & 71.9 \\
\hline Producer price US\$ /ton@ OR & & & & & & & & & 107.5 & 108.0 & 99.0 & 132.4 \\
\hline Producer price US\$/ton @ PR & & & & & & & & & 17.9 & 43.8 & 46.7 & 50.0 \\
\hline FOB price $(\$ /$ ton) raw nuts & (8) & & & & & & & & & & & \\
\hline Producer/ FOB official rates & (8) & & & & & & & & & & & \\
\hline Producer/FOB parallel rates & (8) & & & & & & & & & & & \\
\hline Export Unit Value Raw Cashews (\$/ton) & FAO & 209 & 254 & 242 & 264 & 180 & & & & & & \\
\hline Factory gate price $(\$ /$ ton $)$ & (8) & & & & & & & & & & & \\
\hline Export Unit Value Shelled Cashew (\$/ton) & FAO & 1115 & 1392 & 1735 & 1426 & 1579 & 2680 & 2376 & 2584 & 4157 & 4383 & 2611 \\
\hline \multicolumn{13}{|l|}{ Macro data } \\
\hline Inflation & (10) & & & & & 1 & 2 & 1 & 2 & 1 & 2 & 18 \\
\hline CPI & (10) & & & & & 0.06 & 0.06 & 0.07 & 0.07 & 0.07 & 0.07 & 0.07 \\
\hline Parallel Market Exchange Rate (Mt/\$) & (11) & & & & & & & 195 & 195 & 80 & 75 & 100 \\
\hline Official Exchange Rate (Mt/\$) & (11) & 27.05 & 24.52 & 25.41 & 25.55 & 30.23 & 33.02 & 33 & 32.56 & 32.4 & 35.35 & 37.77 \\
\hline GDP (billions of Meticais) & (12) & & & & & & & & & & 78 & 82 \\
\hline & & & & & & & & & & & & \\
\hline \multicolumn{13}{|l|}{ Notes } \\
\hline \multicolumn{13}{|l|}{ (7) INCAJU (2001) } \\
\hline \multicolumn{13}{|l|}{ (8) Desai (2001) } \\
\hline \multicolumn{13}{|l|}{ (9) (Desai, 2001), WDI; 89/90 base year } \\
\hline \multicolumn{13}{|l|}{ (10) IMF } \\
\hline \multicolumn{13}{|l|}{ (11) WDI } \\
\hline (12) IMF & & & & & & & & & & & & \\
\hline
\end{tabular}




\begin{tabular}{|c|c|c|c|c|c|c|c|c|c|c|c|c|}
\hline Year & & $1982 / 83$ & 1983/84 & $1984 / 85$ & $1985 / 86$ & 1986/87 & $1987 / 88$ & $1988 / 89$ & $1989 / 90$ & 1990/91 & $1991 / 92$ & 1992/93 \\
\hline Export Policy/Tax on FOB & Various & banned & banned & banned & banned & banned & banned & banned & banned & banned & QR (3) & QR (4) \\
\hline \multicolumn{13}{|l|}{ Production } \\
\hline Area Harvested Ha. & FAO & 63,000 & 36,000 & 43,700 & 52,000 & 61,000 & 75,000 & 85,000 & 40,000 & 54,000 & 85,000 & 45,000 \\
\hline Yield kg/ha & FAO & 5,651 & 5,639 & 5,721 & 5,769 & 5,738 & 6,000 & 5,909 & 5,631 & 5,766 & 6,378 & 5,319 \\
\hline Production (tons) & FAO & 35,600 & 20,399 & 25,000 & 30,000 & 35,000 & 45,000 & 50,225 & 22,524 & 31,134 & 54,217 & 23,935 \\
\hline Marketed Raw Cashews (tons) & (1) & 17,617 & 25,311 & 29,177 & 40,075 & 34,882 & 44,453 & 50,226 & 22,106 & 31,122 & 54,104 & 23,935 \\
\hline \multicolumn{13}{|l|}{ Processing } \\
\hline Raw Cashews Processed (tons) & (1) & & & & & & & & & 24,000 & 29,700 & 13,100 \\
\hline Processed Nuts as $\%$ of Marketed Vol. & & & & & & & & & & $77 \%$ & $55 \%$ & $55 \%$ \\
\hline \multicolumn{13}{|l|}{ Exports } \\
\hline Number of Exporters & (2) & & & & & & & & & & 3 & 4 \\
\hline Exported Raw Cashew (tons) & (1) & banned & banned & banned & banned & banned & banned & banned & banned & banned & 6,005 & 8,500 \\
\hline Kernel Exports (tons) & (1) & & & & & & & & & 3,334 & 4,014 & 2,653 \\
\hline Raw Cashew Exports (Mt.) & FAO & & & & & & & & & & & \\
\hline Raw Cashew VX ('000 \$) & FAO & & & & & & & & & & & \\
\hline Shelled Cashew (Kernel) Exports (Mt.) & FAO & 5,800 & 4,100 & 3,100 & 3,100 & 6,000 & 6,800 & 6,000 & 4,300 & 3,800 & 5,500 & 2,300 \\
\hline Shelled Cashew (Kernel) Value Exports ('000 \$) & FAO & 16,106 & 15,314 & 11,549 & 16,716 & 31,088 & 26,478 & 20,022 & 14,288 & 16,033 & 17,592 & 8,151 \\
\hline Value of Exports (Raw and Processed, '000\$) & UCDavis & 12,531 & 9,811 & 9,208 & 7,401 & 16,369 & 15,142 & 9,902 & 14,284 & 15,962 & 27,840 & 24,155 \\
\hline \multicolumn{13}{|l|}{ Prices } \\
\hline Government-Established Producer price (Mt $/ \mathrm{kg})$ & (6) & 5.0 & 5.0 & 10.0 & 10.0 & 10.0 & 105.0 & 165.0 & 200.0 & 380.0 & 460.0 & 560.0 \\
\hline Actual Producer price (Mt $/ \mathrm{kg})$ & (7) & 5.0 & 5.0 & 10.0 & 10.0 & 10.0 & 105.0 & 165.0 & 200.0 & 380.0 & 460.0 & 700.0 \\
\hline Actual Producer price (Mt $/ \mathrm{kg})$ & (8) & 5.0 & 5.0 & 10.0 & 10.0 & 10.0 & 105.0 & 165.0 & 200.0 & 380.0 & 460.0 & 700.0 \\
\hline Real Producer Price (Mt/kg) & (9) & 60.9 & 47.2 & 72.1 & 55.9 & 40.2 & 220.9 & 231.2 & 200.0 & 286 & 238 & 255 \\
\hline Producer price US\$/ton@ OR & & 124.4 & 117.8 & 231.6 & 247.3 & 34.4 & 200.1 & 221.5 & 215.3 & 264.9 & 182.8 & 180.7 \\
\hline Producer price US\$/ton @ PR & & 31.3 & 3.4 & 5.7 & 5.1 & 4.5 & 105.0 & 132.0 & 88.9 & 181 & 164 & 177 \\
\hline FOB price $(\$ /$ ton) raw nuts & (8) & & & & & & & & & & 585 & 689 \\
\hline Producer/ FOB official rates & (8) & & & & & & & & & & $31 \%$ & $26 \%$ \\
\hline Producer/FOB parallel rates & (8) & & & & & & & & & & $28 \%$ & $26 \%$ \\
\hline Export Unit Value Raw Cashews (\$/ton) & FAO & & & & & & & & & & & \\
\hline Factory gate price $(\$ /$ ton $)$ & (8) & & & & & & & 433.0 & 390.0 & 636 & 429 & 271 \\
\hline Export Unit Value Shelled Cashew (\$/ton) & FAO & 2777 & 3735 & 3725 & 5392 & 5181 & 3894 & 3337 & 3323 & 4219 & 3199 & 3544 \\
\hline \multicolumn{13}{|l|}{ Macro data } \\
\hline Inflation & (10) & 29 & 31 & 29 & 39 & 91.05 & 50.14 & 40.15 & 47.01 & 32.93 & 45.49 & 42.2 \\
\hline CPI & (10) & 0.08 & 0.11 & 0.14 & 0.18 & 0.25 & 0.48 & 0.71 & 1 & 1.33 & 1.93 & 2.75 \\
\hline Parallel Market Exchange Rate (Mt/\$) & (11) & 160 & 1450 & 1750 & 1950 & 2230 & 1000 & 1250 & 2250 & 2,100 & 2,800 & 3,950 \\
\hline Official Exchange Rate (Mt/\$) & (11) & 40.18 & 42.44 & 43.18 & 40.43 & 290.73 & 524.64 & 744.92 & 929.09 & 1,435 & 2,517 & 3,874 \\
\hline GDP (billions of Meticais) & (12) & 79 & 75 & 82 & 111 & 122 & 393 & 631 & 991 & 1,341 & 3,943 & 5,053 \\
\hline \multicolumn{13}{|l|}{ Notes } \\
\hline \multicolumn{13}{|l|}{ (1) Deloitte and Touche (1997); INCAJU (2001) } \\
\hline \multicolumn{13}{|l|}{ (2) Deloitte and Touche (1997) } \\
\hline \multicolumn{13}{|l|}{ (3) QR $10,000,60 \%$ tax (FOB-factory gate price) } \\
\hline \multicolumn{13}{|l|}{ (4) QR $10,000,30 \%$ tax (FOB-factory gate price) } \\
\hline \multicolumn{13}{|l|}{ (5) QR $10,000+, 30 \%$ tax (FOB-factory gate price) } \\
\hline (6) INCAJU (2001) FAO pre-78. & & & & & & & & & & & & \\
\hline
\end{tabular}




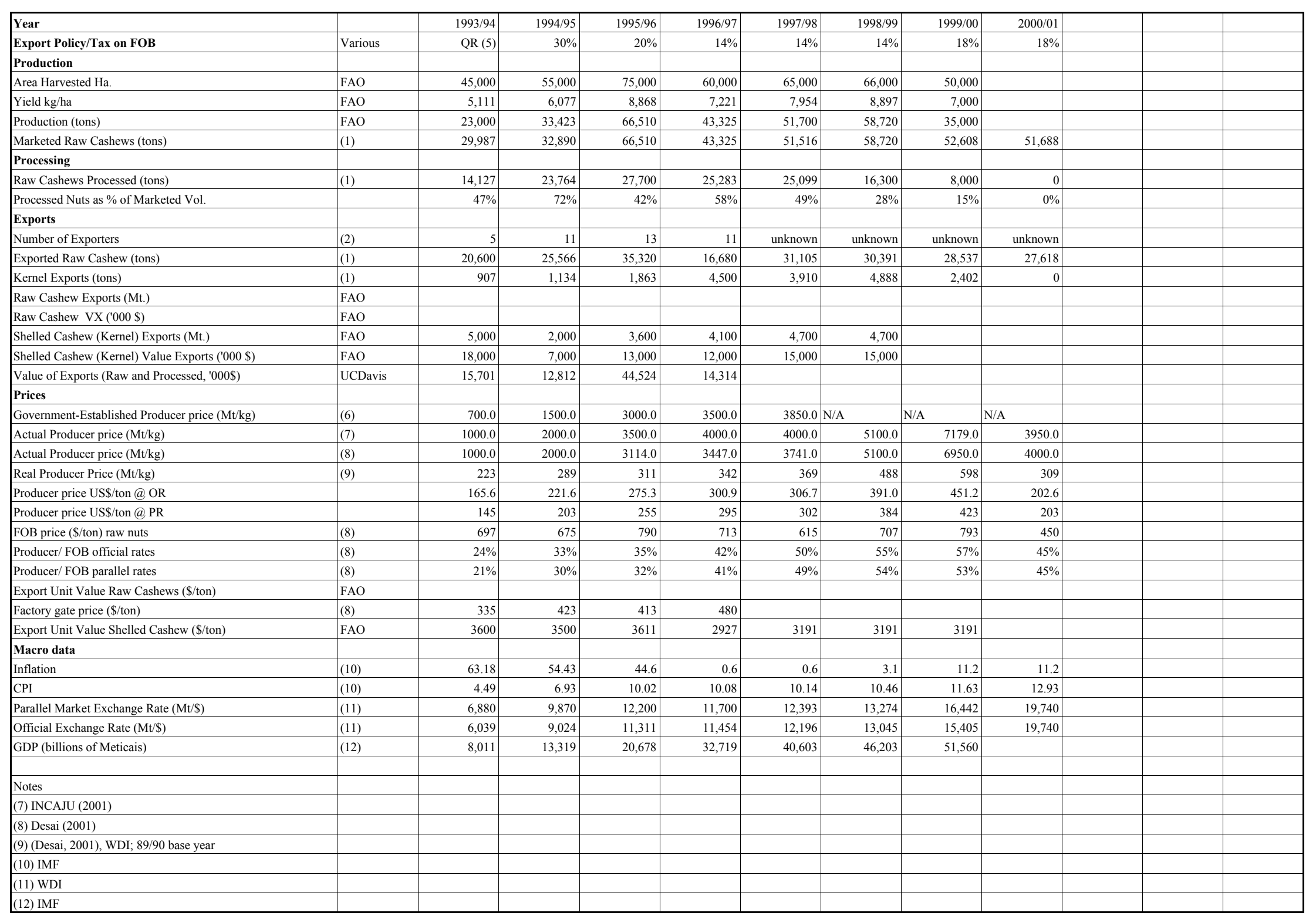

